\title{
Research
}

\section{Scale Mismatches in Management of Urban Landscapes}

\author{
$\underline{\text { Sara T. Borgström }}^{1}, \underline{\text { Thomas Elmqvist }}^{1}, \underline{\text { Per Angelstam }}^{2}$, and $\underline{\text { Christine Alfsen-Norodom }}^{3}$
}

\begin{abstract}
Urban landscapes constitute the future environment for most of the world's human population. An increased understanding of the urbanization process and of the effects of urbanization at multiple scales is, therefore, key to ensuring human well-being. In many conventional natural resource management regimes, incomplete knowledge of ecosystem dynamics and institutional constraints often leads to institutional management frameworks that do not match the scale of ecological patterns and processes. In this paper, we argue that scale mismatches are particularly pronounced in urban landscapes. Urban green spaces provide numerous important ecosystem services to urban citizens, and the management of these urban green spaces, including recognition of scales, is crucial to the well-being of the citizens. From a qualitative study of the current management practices in five urban green spaces within the Greater Stockholm Metropolitan Area, Sweden, we found that 1) several spatial, temporal, and functional scales are recognized, but the cross-scale interactions are often neglected, and 2) spatial and temporal meso-scales are seldom given priority. One potential effect of the neglect of ecological cross-scale interactions in these highly fragmented landscapes is a gradual reduction in the capacity of the ecosystems to provide ecosystem services. Two important strategies for overcoming urban scale mismatches are suggested: 1) development of an integrative view of the whole urban social-ecological landscape, and 2) creation of adaptive governance systems to support practical management.
\end{abstract}

Key Words: management; scale mismatch; urban landscapes

\section{INTRODUCTION}

Half the world's population today lives in urban landscapes, and it is estimated that the urban population will increase to five billion by 2030 (United Nations (U.N.) 2004). In the coming decades, the rapid increase of large urban agglomerations in the developing world, and the transformation of urban landscapes in the developed world, will be among the greatest challenges to ensuring human well-being and a viable global environment (Berkowitz et al. 2003). As one of the major processes of global change, urbanization acts on multiple spatial, temporal, and functional scales, creating a very different social-ecological system compared with other systems (cf. McPherson et al. 1997, Grimm et al. 2000, Kinzig and Grove 2001, Pickett et al. 2001, Alberti et al. 2003, Andersson 2006).

\section{Urban Green-space Management}

Urban growth causes land exploitation that frequently decreases the amount and quality of green space, and leads to fragmentation and isolation of the remaining parcels of green space (Schwartz 1997, Young and Jarvis 2001, Stenhouse 2004, Sandström et al. 2006b). These declining urban ecosystems are poorly understood and often undervalued. Despite this, they are assumed to be critical sources for generating ecosystem services that are of significant value to human well-being (Bolund and Hunhammar 1999). For example, urban vegetation may significantly reduce air pollution (Beckett et al. 1998, Jansson and Nohrstedt 2001, Yang et al. 2005), mitigate the urban heat island effect (McPherson et al. 1997), reduce noise (Berglund et al. 2004), and enhance health; furthermore, it has important recreational and cultural values for urban citizens (Ulrich 1984, Vandruff et al. 1995, Grahn and Ottosson 1998). 
The high degree of spatial heterogeneity, the human-driven disturbance regimes, and the diversity of interests in every parcel of land in urban landscapes create extraordinary challenges for urban green-space planning and practical management (Zhang et al. 2004, Sandström 2006a). At the same time, urban landscapes also represent an important arena for studying interactions in complex social-ecological systems (McPherson et al. 1997, Grimm et al. 2000, Kinzig and Grove 2001, Pickett et al. 2001, Alberti et al. 2003, Elmqvist et al. 2004, Grimm and Redman 2004, Andersson 2006). A recent argument for increased scientific analyses of urban landscapes is based on the view that urban areas constitute large-scale experiments on the effects of global change on ecosystems because significant warming, increased nitrogen deposition, and human domination of ecosystem processes are already prevalent in urban environments (Carreiro and Tripler 2005). One of the most important challenges to sustainability is how to manage social-ecological systems, such as cities, in a way that does not erode their adaptive capacity and ability to cope with environmental changes (cf. Gunderson et al. 1995). Among other things, this implies recognition of urban socialecological systems as complex adaptive systems with characteristics such as non-linearities, thresholds, and interactions across multiple scales (cf. Holling 1992, 1995, 2001, Peterson et al. 1998, Levin 1999, Scheffer et al. 2001, Angelstam et al. 2004). The focus of this paper is on how cross-scale interactions are handled within urban green-space management.

\section{Scales in Management}

One important cause of failures in natural resource management is mismatch of scales (Folke et al. 1998). These mismatches occur when the scales of ecological dynamics and the scales of social organization for management are aligned in a way that negatively affects the ecosystem (Cumming et al. 2006). Among other things, incomplete knowledge of ecosystem dynamics and institutional constraints frequently leads to institutional frameworks for management that do not match the scales of ecological patterns and processes. For example, the scale of monitoring and decision making often does not match ecological spatial, temporal, or functional scales (Lee 1993, Gunderson et al. 1995, Holling and Meffe 1996, Cleveland et al. 1996, Folke et al. 1998, Hobbs 1998,
Levin 2000, Carpenter and Gunderson 2001, Young 2002, 2003, Angelstam 2003).

Ecological scales can be described using a threepart typology: spatial, temporal, and functional scales (Lee 1993). Spatial mismatches occur when the boundaries of management do not coincide with the boundaries of the ecological entity (Christensen et al. 1996, Folke et al. 1998, Hobbs 1998). Management regimes are also embedded into a larger social context of territorial divisions, politics, economics, and culture that might cause both spatial and temporal scale mismatches (Young 2002). Temporal mismatches represent the discrepancies of the time horizons of planners and politicians relative to those of ecological and social changes (Christensen et al. 1996, Folke et al. 1998). A slow response by society to fast ecological changes is another example of temporal mismatch (Folke et al. 1998). A match of functional scales means recognition of important ecological functions and processes, and their connections (Lugo et al. 1999), as well as disturbance regimes (Engstrom et al. 1999, White et al. 1999). A functional scale mismatch includes the neglect of multiple crossscale interactions of ecosystems, and largely ignores the basic characteristic of an ecosystem as a complex adaptive system (Christensen et al. 1996). There are several studies on misfits of scale between ecosystem dynamics and management regimes. Some examples are the misperception of scales of fish population dynamics within fisheries management (Wilson et al. 1999), administrative divisions in management of long-distance migratory organisms and pollutants (Young 2002), management units not reflecting ecological dynamics in restoration of agricultural landscapes (Briggs 2001, Saunders and Briggs 2002), and institutional frameworks unsuited for integration of development and conservation in forest projects (Brown 2003). However, there is still a shortage of studies evaluating the occurrence of such scale mismatches in urban landscapes.

In this paper, we hypothesize that scale mismatches are more pronounced in urban landscapes than in most other social-ecological systems. The rationale for this is that a) urban social-ecological landscapes are extremely heterogeneous, meaning that the spatial land-use units are small, scattered, and dissimilar (cf. Pickett et al.1997, 2001, Alberti et al. 2003, Berling-Wolff and Wu 2004), b) the multitude of spatially oriented subdivisions among different administrative tasks make it exceedingly hard to 
coordinate and match to ever-changing ecological dynamics (Pickett et al. 1997, 2001), c) the rate of disturbance and change is high (Collins et al. 2000, Kinzig and Grove 2001, Pickett et al. 2001) and d) there is very little space for ecological dynamics in time and space because a large part of the urban landscape is locked into intensive land use.

In order to test the current hypothesis of scale mismatches on a qualitative, empirical analysis of green-space management practices in the context of urban social-ecological complexity, the following research objectives were addressed:

- Do current management practices recognize temporal and spatial scales in the ecosystem?

- Do current management practices recognize complexity, interconnectedness and dynamic characteristics of ecological systems?

- What strategies are currently feasible for reducing scale mismatches in urban landscapes?

\section{METHODS}

\section{Analysis Framework}

For the analysis, two frameworks were synthesized: ecosystem management and hierarchical planning. To enable an empirical analysis of practical management of scales in the context of socialecological complexity, we used the theoretical framework of ecosystem management. Ecosystem management is based on an ecosystem approach, which means that it is the ecological considerations that govern management (Slocombe 1993, 1998, Grumbine 1994, Christensen et al. 1996, Haufler et al. 1999, Yaffee 1999, Dale et al. 2000). We used the theoretical criteria for ecosystem management, synthesized and published by the Ecological Society of America (Christensen et al. 1996) to investigate management practices. Of the eight criteria (Christensen et al. 1996), four directly concern scale. Criteria 1) "long-term sustainability is a fundamental value" and 2) "attention to context and scale" cover spatial and temporal scales, whereas ecosystem management criteria 3) "understanding of complexity and interconnectedness" and 4) "recognition of the dynamic character of ecosystems" cover functional scales, including interactions of both spatial and temporal scales.

Ecosystem management used for protection, maintenance, and restoration of ecosystem services requires not only planning at multiple scales, but also crossing and linking of hierarchical scales to be able to recognize ecosystem dynamics. However, cross-scale issues create the most challenges for planning and management (Folke et al. 1998, Holling et al. 2002, Angelstam et al. 2003a, Lazdinis and Angelstam 2004). An approach to dealing with these cross-scale challenges has been developed for forest production systems (Weintraub and Cholaky 1991, Jonsson et al. 1993, Higman et al. 1999) that involves assessing and planning at different scales in a hierarchy: strategic, tactical, and operational (Raivio et al. 2001, Angelstam et al. 2003a, 2005, Szaro et al. 2005). The first process is strategic planning to decide long-term goals. In a conservation approach, this includes estimating regional gaps in the representation of different ecosystems (Scott et al. 1993, Angelstam and Andersson 2001, Lõhmus et al. 2004). The second phase is the tactical planning, which means selecting from different alternatives within the strategic goals, but over a shorter time horizon and at smaller spatial scales. At this level, the functionality of the ecological networks for both viable populations and ecosystem processes needs to be assessed (Roberge and Angelstam 2004, Angelstam et al. 2004). The third phase in the hierarchy concerns operational planning for practical implementation at a local level over relatively short time perspectives, by incorporating the concepts of protection, practical management, and restoration (Angelstam 2003, Stanturf and Madsen 2005).

The starting point for this study is the practical management of urban green spaces at the operational scale. The ecosystem management criteria were reformulated into analysis questions about how the scale hierarchy is handled in management (Table 1). The first ecosystem management criterion requires that long-term sustainability is a fundamental value in management. This criterion addresses the temporal strategic scale. Two questions were formulated concerning the main aim of management and whether long-term sustainability is an explicit goal of the management. The second ecosystem management criterion requires management to notice context and scale, and thereby addresses the full range of hierarchical scales, from operational to strategic, in both temporal and spatial senses. The 
temporally oriented analysis questions concerned the time perspectives in use, the short-term goals, and whether these goals are connected to long-term goals by monitoring and evaluation procedures. In addressing spatial scales, the questions concerned what levels of biological organization are managed and what are the boundary determinants, and the recognition of surrounding area management and the regional context. The third and fourth criteria address functional scales by requiring that management recognizes the complexity,

interconnectedness, and dynamism of the ecosystem. The questions concerned the manager's perception of disturbances, management intensity, reasons for variation in management, and identification of ecological functions and processes.

\section{Study Area and Data Collection}

As part of the Millennium Ecosystem Assessment (Elmqvist et al. 2004), the study was performed during the autumn of 2002 in five urban green spaces within the Greater Stockholm Metropolitan Area (GSMA), Sweden: the National Urban Park, the Stockholm Woodland Cemetery, the Flaten Nature Reserve, the Tyresta Forest, and the Tyresån Watershed (Fig. 1). All the selected areas are part of the GSMA regional green structure (Append. 1). To ensure a good representation of the heterogeneity of this green structure, site selection was based on several parameters: distance to the city, degree of protection, property rights and management regime, main uses, size, and type of landscape (Table 2, Append. 2).

The main data sources were written management documents and interviews with key informants (Append. 2). As the focus was on current management practices, the written material was collected from a 10-year time span (1992-2002), and included plans, referrals, annual reports, protocols, general descriptions, and information brochures (Table 2, Append. 2). This broad selection of written material covered the management from initiation, through planning and implementation, to revision and evaluation, and enabled analysis of both practices in use and management visions. The interviews clarified the documented data and added information about current management. The advantage to this kind of data combination is the broad basis on which it is gathered, which increases the validity of the analysis as a whole (Patton 1987). To qualify as a key informant, one had to be either currently formally responsible for management at some level, or have been in the past. Open-ended key questions were formulated in advance, and more case-specific questions were created during the interviews. This flexibility was chosen for adaptation to each specific case and interview situation. In total, 20 key informants were interviewed and, depending on the management system and the relevance of the written material, the number of informants varied from one to eight (Table 2, Append. 2). The interviews lasted for 30-120 minutes. All informants were given the opportunity to approve the reviews based on the interviews.

Both the written material and the informant data were analyzed through the same ecosystem management criteria scheme (Table 1). Details found in the analysis were classed as supportive or non-supportive to each ecosystem management criterion, hence indicating how scales are managed in the green spaces.

\section{RESULTS}

The results from the comparison of scale management in the five green spaces are presented in three sections (spatial, temporal, and functional scales), each with examples from the green spaces. A complete presentation of the results for each green space is found in Table 1.

\section{Spatial Scales}

The analysis questions addressing spatial scales concerned the foundation of the boundaries of the area, the level of biological organization in management, the recognition of management of surrounding areas, as well as the broader regional context of the green space.

All the studied management systems are locally created and specific to each green space. Generally, the management boundaries are not based on ecological restrictions; rather they are decided by socioeconomic factors such as ownership, administrative divisions, or former land use. The exception is the Tyresån Watershed, where the geographical extent of the watershed defines the boundaries of management (Länsstyrelsen i Stockholms län 1996:1). In the Tyresta Forest, 
Table 1. Analysis results for each green space in relation to the ecosystem management criteria (Christensen et al. 1996) and the analysis questions. The results are interpreted as indicating (+) or not indicating (-) criteria fulfillment. For case-specific references, see Append. 3. * indicates that the statement is only valid for some managers in the National Urban Park.

\section{Ecosystem manag- Long-term sustainability is a fundamental value (Strategic scales) ement criterion 1}

Analysis questions $\S$ What is the main aim of management?

$+$

$\S$ Is the goal of long-term sustainability

explicit in the management documents?

National Urban
Park

- to preserve natural, cultural, and recreational values in the vicinity of Stockholm within the legal framework of a National Urban Park - explicit in some management documents (from $2 / 7$ managers) *

Stockholm Woodland - to preserve the design and functions of the Cemetery cemetery in perpetuity, as a UNESCO World Heritage Area - no

Flaten Nature Reserve

- to restore and develop natural, recreational, and cultural values, using the legal framework of a nature reserve - no

Tyresta Forest

- to preserve nature in its natural condition and facilitate public experiences, using the legal framework of a nature reserve and national park

- no

Tyresån Watershed - to preserve and develop the natural values despite urbanization in the watershed - no
- implicit in the formal protection as a National Urban Park - the Municipalities use Agenda 21 sustainability framework for management

- preservation in perpetuity is an explicit goal in the World Heritage appointment

- implicit in the aim of preservation by protection as a nature reserve

- implicit in the aim of preservation by protection as a national park and nature reserve

- implicit in the preservation aim of the project
- not explicit in most of the practical management documents $(5 / 7) *$

- not explicit in the practical management documents

- not explicit in the practical management documents

- not explicit in the practical management documents

- not explicit in the practical management documents - no formal protection as a whole
Ecosystem management criterion 2

Analysis questions
Attention to context and scale (Operational to strategic scales and their interactions)

$\S$ What levels of biological organization are managed?

$\S$ How are the boundaries of the area decided upon?

$\S$ What are the short-term goals?

$\$$ What are the time perspectives in management?

$\S$ How is practical management evaluated?

$\S$ Is management adjusted to management of

neighboring areas and the regional context? 


\section{National Urban} Park
- management levels: species (oaks), biotope, and landscape.*

- boundaries are decided by land ownership and administrative divisions

-examples of short-term goals are regeneration of oaks, leave forests for free development, garden management in the parks, improving water quality, and meadow restoration* - practical management is on an annual basis* (not all managers have an active management) - some management plans (from the 1990s) are under revision, whereas other managers are still developing their first plans*

- current management plans lack priorities in time.

- historical material is used in management planning*

- monitoring is very limited, except for the lake management*

- there is no evaluation of practical management in relation to the management plans, except for the lake management* - neighboring formal stakeholders are part of the management cooperative forum.

- limited communication between managers within the area despite the existing cooperative forum (the lake manager is not part of the cooperative forum)

- the regional green structure is mentioned in some management plans*

Stockholm Woodland - management levels: species (pines), biotope, Cemetery and cemetery

- boundaries are decided by land ownership - short-term goals concern satisfying the visitor's expectations of the cemetery, e.g., watering lawns and cleaning dead wood from the area, and also regenerating the pine forest - historical material is used in management planning

- practical management is on an annual basis - the first plan from 1994 has not been revised and lacks priorities in time

- there is no monitoring

- there is no evaluation of practical

management in relation to the management

plan

- no communication with neighboring

stakeholders

- the regional green structure is not mentioned in the management documents
- multiple biological levels - boundaries are not are managed based on ecological - historical material is used considerations in management planning - meso-term goals are - short-term goals seem to not defined in the be in line with main aim of management plans* the management - the practical lake management is connected to the management plan and long-term goals by continuous evaluation procedures - neighboring managers are involved in

management* - the regional scale context is mentioned in plans*
- evaluation procedures are missing, indicating a potential gap between and the management plan and long-term goals* - limited communication between managers within the area practical management
- multiple biological levels are managed

- historical material is used in management planning - short-term goals seem to be in line with main aim of the management
- boundaries are not based on ecological

considerations

- meso-term goals are not defined in the

management plans - evaluation procedures are missing, indicating a potential gap between practical management and the management plan and long-term goals - no communication with neighboring stakeholders - the regional scale context is not mentioned in the management plans 


\section{Flaten Nature Reserve}

Tyresta Forest -management level: biotopes, e.g., forest, meadow, lake

- boundaries are decided by land ownership and administrative divisions

- short-term goals concern restoring meadows by clearing and grazing, leaving forests for free development, cleaning the nutrientoverloaded inflow to the lake, and developing public access

- historical material is used in management planning

- practical management is on an annual basis - the first plan from late 1990s has not been revised and lacks priorities in time

- there is very limited monitoring in the terrestrial biotope

- the lake is monitored and evaluated by water quality indicators on an annual basis

- the terrestrial practical management is not evaluated in relation to the management plan - very limited communication with neighboring stakeholders

- the managers are aware of the regional green structure but it's not mentioned in the management documents
- historical material is used - one biological level is in management planning managed - short-term goals seem to - boundaries are not be in line with main aim of based on ecological the management - the practical lake considerations - meso-term goals are not defined in the management plans - evaluation procedures are missing for the terrestrial management, indicating a potential gap between practical management and the management plan and long-term goals - limited communication between managers in the area, e.g., division between meadow creation and lake management - limited communication with neighboring stakeholders - the regional-scale context is not mentioned in the management plans

-management levels: species (endangered) and - multiple biological levels - no time priorities in the biotopes, e.g., forests and lakes are managed current plan - the outer boundaries - boundaries are decided by land ownership for the forest as a whole, the division between the national park and the nature reserve has an ecological basis

- short-term goals concern enhancing accessibility, leaving the forest for free development and keeping the meadows open by clearing and grazing

- practical management is on an annual basis

- the first plans for the whole forest from 1993 have just been revised

- the current plan lacks priorities in time

- frequent monitoring, but not primary for

management evaluation purposes

- there is an annual revision of the management in relation to the management plan

- limited communication with neighboring

stakeholders

- the importance of the forest as a core area in relation to the regional green structure is mentioned in the management plans
- the inner boundaries of

national park/nature reserve are based on ecological considerations - short-term goals seem to the management - the practical management is connected to the management plan and long-term goals by continuous evaluation procedures

- the regional-scale context is mentioned in the plan are not based on

(n)

$$
\text { is mentioned in the plan }
$$
- short-term goals seem to with neighboring
be in line with main aim of stakeholders ecological considerations - limited communication 
Tyresån Watershed - management levels: watershed and biotopes, - multiple biological levels e.g., lakes and forests

- boundaries are set by the watershed

- short-term goals concern gathering more

are managed

- ecological considerations

the watershed and boundaries

developing the cooperation between

stakeholders

- historical material is used in management

planning

- planning is done in 6-year periods, a new

plan has recently been developed

- monitoring constitutes a large part of

management for adaptation to current and

potential status of the watershed

- the current management was evaluated

during the creation of the new plan

- neighboring stakeholders are part of the

project

- the starting point for the project is to manage

a part of the regional blue structure

- historical material is used

in management planning

- short-term goals seem to

be in line with main aim of

the management

- the plan is divided into

priorities in time.

- monitoring and

evaluation is prioritized in

management

- cooperation between

stakeholders in and

surrounding the watershed

is one of the main goals of

the project

- the regional scale

constitutes the starting

point for the project

Ecosystem management criteria 3 and 4

Analysis questions

at critical ecological processes and functions are recognized in management? $\S$ How are changes and disturbances handled?

$\S$ Does management vary over the area?

§ Is management intensive?

National Urban Park

- recognized: clearing and grazing for meadow biodiversity, dead wood and tree age

\section{Management efforts recognize the complexity, interconnections, and dynamic character of ecological systems (Functional scales)} diversification as important for forests, and biochemical cycles as important in the lakes* - ecological core areas and links are identified within and outside the area*

- in some parts no ecological functions and processes have been identified and aesthetical values are prioritized *

- management varies according to manager/

biotope/use/value priorities *

- lake management is separated from other

types of management

- management is intensive in some parts, e.g.,

in parks, gardens, meadows
- several processes and functions are identified by some managers and cover several scales *

- variation in management by biotope *
- some managers have not identified ecological processes and functions, e.g., removal of dead wood*

- the interactions of biotopes are not recognized, e.g., lakes with other areas in the watershed

- recognized processes and functions only at biotope scale, e.g., dead wood in forest biotopes * 
Stockholm Woodland - recognized: age diversity of pine trees for Cemetery

\section{Flaten Nature Reserve}

Tyresta Forest

Tyresån Watershed - hydrological and biochemical cycles and alkalinity are recognized as important processes

- water level variations are regulated to secure settlements and other land uses from flooding - nutrient load is recognized as a disturbance to be fought

- the watershed is one management unit, besides the biotopes

- management varies according to biotope status, potential values, and anticipated impact in the rest of the watershed

- management is intensive at some biotopes, e. g., wetland restoration sites
- several processes and functions are identified and managed - variation in management by biotope

- interactions between biotopes are not recognized, e.g., grassland and pine forest - the recognized processes and functions concern only the pine forest - compromises between values result in suppression of ecological functions, e.g., removal of dead wood

- several key processes and -interactions between functions are identified and managed - variation in management by biotope

biotopes are not recognized, e.g., the lake, the meadows, and the forests - recognized processes and functions only at biotope scale, e.g., lake management not watershed management

- several key processes and -interactions between functions are identified biotopes are not and managed recognized, e.g., - variation in management meadows and forests by biotope - recognized processes and functions only at biotope scale, e.g, lake alkalinity but not watershed alkalinity - compromises between values result in suppression of ecological functions, e.g., forest fires are suppressed

- several processes and functions are identified and managed

- the watershed approach indicates a priority to cross-scale interactions - compromises by multiple values result in suppression of ecological functions, e.g., waterlevel variations 
Fig. 1. The study area, consisting of the regional green structure of the Greater Stockholm Metropolitan Area and the five green spaces: the National Urban Park, the Stockholm Woodland Cemetery, the Flaten Nature Reserve, the Tyresta Forest and the Tyresån Watershed. (Ground map from the Office of Regional Planning and Urban Transportation, (online) URL: http://www.rtk.sll.se.)

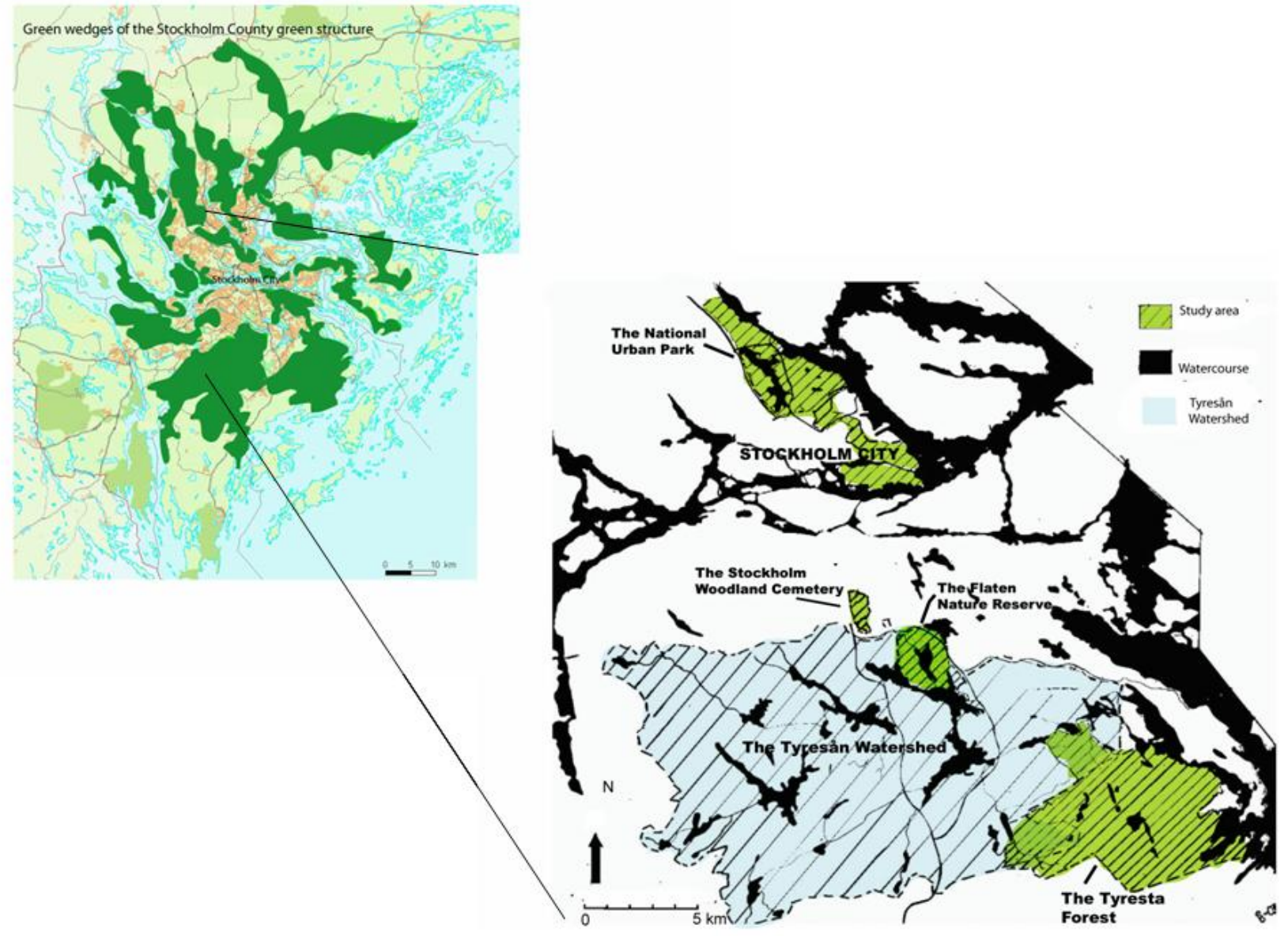

ecological considerations determined the division between the nature reserve and the national park, but the outer boundary was set by socioeconomic determinants.

In all areas but the Flaten Nature Reserve, multiple biological levels are managed and the main management elements are patches of different biotopes within the green space. These biotope patches seem to be managed separately, without recognition of the interactions among them, e.g., lakes, forests, and meadows. One example of this is the lack of dialogue between the managers matching the hydrological links between land and 
Table 2. Description of the five studied green spaces. For an in-depth description, see Appends. 1-3 and Borgström (2003).

\begin{tabular}{|c|c|c|c|c|c|}
\hline & $\begin{array}{l}\text { National Urban } \\
\text { Park }\end{array}$ & $\begin{array}{l}\text { Stockholm Woodland } \\
\text { Cemetery }\end{array}$ & $\begin{array}{l}\text { Flaten Nature } \\
\text { Reserve }\end{array}$ & Tyresta Forest & Tyresån watershed \\
\hline Distance to city & In the city & On the city fringe & $10 \mathrm{~km} \mathrm{SE}$ & $20 \mathrm{~km} \mathrm{SE}$ & $10-20 \mathrm{~km} \mathrm{~S}$ \\
\hline Protection & $\begin{array}{l}\text { By NUP law since } \\
1995\end{array}$ & $\begin{array}{l}\text { UNESCO world } \\
\text { heritage site since } \\
1994\end{array}$ & $\begin{array}{l}\text { Nature reserve } \\
\text { since } 2004\end{array}$ & $\begin{array}{l}\text { Nature reserve and } \\
\text { National park since } \\
\text { the } 1990 \text { s }\end{array}$ & $\begin{array}{l}\text { No formal } \\
\text { protection as a } \\
\text { whole }\end{array}$ \\
\hline $\begin{array}{l}\text { Property rights and } \\
\text { management orga- } \\
\text { nization }\end{array}$ & $\begin{array}{l}\text { Owned and } \\
\text { managed by } \\
\text { several actors; the } \\
\text { Royal Djurgården } \\
\text { Administration } \\
\text { manages } 80 \%\end{array}$ & $\begin{array}{l}\text { Owned by } \\
\text { Stockholm Munici- } \\
\text { pality and } \\
\text { managed by the } \\
\text { Stockholm Cemeteries } \\
\text { Administration }\end{array}$ & $\begin{array}{l}\text { Owned and } \\
\text { managed by the } \\
\text { Stockholm Munici- } \\
\text { pality; the lake is } \\
\text { owned by } \\
\text { Stockholm Vatten } \\
\text { AB }\end{array}$ & $\begin{array}{l}\text { Mostly owned by } \\
\text { the State and } \\
\text { managed by the } \\
\text { Tyresta Foundation }\end{array}$ & $\begin{array}{l}\text { Six municipalities } \\
\text { with managment } \\
\text { resonsibility that is } \\
\text { co-ordinated by the } \\
\text { Tyresån Project }\end{array}$ \\
\hline Protected values & $\begin{array}{l}\text { Recreational, cultural, } \\
\text { natural }\end{array}$ & Recreational, cultural & Recreational, natural & Recreational, natural & $\begin{array}{l}\text { Watershed; forestry, } \\
\text { agriculture, settle- } \\
\text { ments, and } \\
\text { recreational, cultural, } \\
\text { and natural values }\end{array}$ \\
\hline Size & $27 \mathrm{~km}^{2}$ & $1 \mathrm{~km}^{2}$ & $6 \mathrm{~km}^{2}$ & $47 \mathrm{~km}^{2}$ & $240 \mathrm{~km}^{2}$ \\
\hline Landscape & $\begin{array}{l}\text { Both forests and } \\
\text { park landscape }\end{array}$ & $\begin{array}{l}\text { Both parks and } \\
\text { more natural pine } \\
\text { forests }\end{array}$ & $\begin{array}{l}\text { Flaten Lake } \\
\text { surrounded by } \\
\text { mainly forests and } \\
\text { some open land }\end{array}$ & $\begin{array}{l}\text { Coniferous forests, } \\
\text { of which some are } \\
\text { old growth }\end{array}$ & $\begin{array}{l}38 \text { connected lakes } \\
\text { and watershed } \\
\text { inhabiting approx. } \\
200000 \text { people }\end{array}$ \\
\hline Informants & $\begin{array}{l}\text { Axelsson, Rebecca } \\
\text { - Stockholm } \\
\text { County Administr- } \\
\text { ation, } \\
\text { Eriksson, Rolf G. - } \\
\text { Solna Municipality, } \\
\text { Eriksson, Rune - } \\
\text { Akademiska hus, } \\
\text { Halling, Claes - } \\
\text { Stockholm County } \\
\text { Administration, } \\
\text { Linder, Per - Solna } \\
\text { Municipality, } \\
\text { Lindgren, Gunilla - } \\
\text { Stockholm Vatten } \\
\text { AB, } \\
\text { Niklasson, Henrik } \\
\text { - Royal Djurgården } \\
\text { Administration, } \\
\text { Nilsson, Jerry - } \\
\text { Stockholm Munici- } \\
\text { pality, } \\
\text { Wallström, Bo - at } \\
\text { Vasakronan }\end{array}$ & $\begin{array}{l}\text { Lehtimaa, Erkki - } \\
\text { Stockholm Cemetery } \\
\text { Administration, } \\
\text { Nordström, Leif - } \\
\text { Stockholm Cemetery } \\
\text { Administration, } \\
\text { Olsson, Börje - } \\
\text { Stockholm Cemetery } \\
\text { Administration, } \\
\text { Rönnbäck, Hedvig } \\
\text { - Stockholm City } \\
\text { Museum, } \\
\text { Westerdahl, Maria } \\
\text { - SWECO }\end{array}$ & $\begin{array}{l}\text { Främborg, Joakim } \\
\text { - Skrubba Gård, } \\
\text { Karlström, Göran - } \\
\text { Fornminnesgruppen } \\
\text { in Flaten, } \\
\text { Lindgren, Gunilla - } \\
\text { Stockholm Vatten } \\
\text { AB, } \\
\text { Nilsson, Helen - } \\
\text { Stockholm Munici- } \\
\text { pality, } \\
\text { Olsson, Bo - } \\
\text { Swedish Society } \\
\text { for Nature } \\
\text { Conservation }\end{array}$ & $\begin{array}{l}\text { Matzon, Curt- } \\
\text { Managing Director } \\
\text { of the Tyresta } \\
\text { Forest }\end{array}$ & $\begin{array}{l}\text { Andersson, Göran - } \\
\text { project coordinator } \\
\text { of the Tyreså } \\
\text { Project }\end{array}$ \\
\hline
\end{tabular}




\begin{tabular}{|c|c|c|c|c|c|}
\hline Documents & $\begin{array}{l}\text { Plans: } \\
\text { Akademiska hus } \\
\text { AB (1998) } \\
\text { Kungliga Djurgårdens } \\
\text { förvaltning (1993- } \\
\text { 1994) and (1995) } \\
\text { Länsstyrelsen i } \\
\text { Stockholms län } \\
\text { (1996b), (1999) } \\
\text { and (2003) } \\
\text { Solna stad } \\
\text { (1997:1-2) and } \\
\text { (1999:1-2) } \\
\text { Stockholm stad } \\
\text { (1994) } \\
\text { Working documents: } \\
\text { Bråvander et.al. } \\
\text { (2002) } \\
\text { Reports: } \\
\text { Herdin C. (2002) } \\
\text { Länsstyrelsen i } \\
\text { Stockholms län } \\
\text { (2001) } \\
\text { Solna stad, } \\
\text { Stockholms fritids- } \\
\text { förvaltning (1992) } \\
\text { Stockholm stad } \\
\text { (1997) } \\
\text { Wirén L. (2002) }\end{array}$ & $\begin{array}{l}\text { Plans: } \\
\text { Kyrkogårdsförvalt- } \\
\text { ningen (2001) and } \\
(2003) \\
\text { Westerdahl, M. } \\
\text { (1995) } \\
\text { Reports: } \\
\text { Riksantikvarieämbetet } \\
\text { (2002) } \\
\text { Westerdahl, M. } \\
\text { (1991) }\end{array}$ & $\begin{array}{l}\text { Plans: } \\
\text { Stockholm stad } \\
(1994),(1999) \text { and } \\
(2002) \\
\text { Working documents: } \\
\text { Lindholm, A. and } \\
\text { Kukka, J. } \\
(2001: 1-2) \\
\text { Stockholm stad } \\
\text { GFK (2001) } \\
\text { Stockholm stad. } \\
\text { (2002) } \\
\text { Reports: } \\
\text { Stockholm vatten } \\
\text { AB, Report no } \\
\text { MV00048 (2000) }\end{array}$ & $\begin{array}{l}\text { Plans: } \\
\text { Länsstyrelsen i } \\
\text { Stockholms län } \\
\text { (1993) } \\
\text { Naturvårdsverket } \\
\text { (1993) } \\
\text { Working documents: } \\
\text { Stiftelsen Tyrestas- } \\
\text { kogen (1993), } \\
\text { (2000),(2001:1-2) } \\
\text { and (2002) } \\
\text { Reports: } \\
\text { Grundsten, C. } \\
\text { (2001) } \\
\text { Magnusson, L. } \\
\text { (1993) } \\
\text { Naturvårdsverket } \\
\text { (1997) }\end{array}$ & $\begin{array}{l}\text { Plans: } \\
\text { Länsstyrelsen i } \\
\text { Stockholms län } \\
(1996: 1) \text { and } \\
(2002: 2) \\
\text { Working documents: } \\
\text { Länsstyrelsen i } \\
\text { Stockholms län } \\
\text { (2002:1) } \\
\text { Reports: } \\
\text { Tyresån project } \\
\text { (online) URL: http: } \\
\text { //www.tyresan.org }\end{array}$ \\
\hline
\end{tabular}

watercourses in the watersheds in the Flaten Nature Reserve and in the National Urban Park. In the Flaten Nature Reserve, the water manager tries to identify sources of nutrient loss within the watershed and takes measures to diminish them (Lindgren, pers. comm.). Meanwhile, the terrestrial manager clears land overgrown by shrubs, and initiates cattle grazing to enhance plant biodiversity, which may impact hydrology and nutrient inflow to the lake (cf. Turner et al. 2001, Scrimgeour and Kendall 2002). There is no communication about these activities between the managers who match these ecological connections (Lindgren, pers. comm.; Jerry Nilsson, pers. comm.). The National Urban Park is managed by several different stakeholders, many of whom belong to a cooperative forum for enhanced communication (Table 2, Append. 3). However, the watercourse manager is not a member of this forum (Lindgren, pers. comm.), and even among the managers represented in the forum, recognition of ecological functions and processes across management boundaries is missing (Axelsson, pers. comm.; Niklasson, pers. comm.).
In several of the management documents, the GSMA regional green structure is mentioned as an important setting for management. However, interactions between the green space and the surrounding landscape, e.g., through potential ecological links (cf. Lundberg and Moberg 2003) such as green corridors, hydrological connections, and migrating organisms, are seldom matched by dialogue between neighboring managers. In practical management, the regional context, as well as the immediate surrounding area, are commonly neglected. In the Stockholm Woodland Cemetery, management efforts are limited to the area inside the wall that surrounds the cemetery. There is no dialogue between cemetery management and the different stakeholders in the important buffer zone surrounding the cemetery. When a development project was planned and later carried out at the southern boundaries of the buffer zone, the cemetery manager was not informed (Bo Olsson, pers. comm.). In the National Urban Park, especially important ecological links to the surrounding area have been identified, and some of the managers are also responsible for land-use planning and 
management outside the park (Table 2, Append. 3). However, this does not necessarily mean that the surrounding area is managed in accordance with the aims and goals of the park management (Borgström 2003, Elmqvist et al. 2004). The use of the nature reserves in the Tyresta Forest as a buffer zone to the national park indicates an understanding of the complexity of cross-scale interactions. The surrounding municipalities are also part of the steering group of the Tyresta Forest (Naturvårdsverket 1993), but in this group communication focuses on management within the Tyresta Forest (Matzon, pers. comm.). Still, there is very limited communication with the neighboring stakeholders, including the municipalities, about potential alignment of the surrounding area's management with the goals of the Tyresta Forest (Matzon, pers. comm.). The recent informal discussions about how to sustain the green corridors between the Flaten Nature Reserve and the Stockholm Woodland Cemetery and other green spaces in the southern GSMA constitute an example of broadening the spatial perspectives in a more practical sense (Jerry Nilsson, pers. comm.). Furthermore, the existence of the Tyresån Watershed also indicates an increased recognition of the regional scale.

\section{Temporal Scales}

The temporally oriented analysis questions concerned the time perspectives in use, the shortterm goals, and whether these goals are connected to long-term goals by monitoring and evaluation procedures.

Short-term scales as well as long-term scales are recognized in green space management. In all but the Tyresta Forest, the managers have collected historical data that connects current ecosystem conditions to the broader temporal context of former land uses. Long-term sustainability is not an explicit goal in most green-space management, but is implicit in the main aim of preservation and protection in all the areas. Most practical management and reporting are done on an annual basis and seem to be connected to the main aims and long-term goals in the green spaces. In the Stockholm Woodland Cemetery, for example, the goal is to preserve the "original pine forest in perpetuity" due to the UNESCO World Heritage designation (Westerdahl 1995). In line with that goal, the managers have developed a program for pine tree regeneration as an annual activity directly linked to the long-term vision for the area (Westerdahl 1995; Lehtimaa, pers. comm.).

One important link between annual planning and the long-term goals are the management plans. The management plans in use date back to when the green spaces were assigned their current protection status in the 1990s, and most of them do not include a formal revision process, except for the Tyresån Watershed, where planned revisions are carried out every $6^{\text {th }}$ year (Länsstyrelsen i Stockholms län 2002a). According to the interviews, the plans are used only to a very limited extent for annual planning in the National Urban Park, the Flaten Nature Reserve, and the Stockholm Woodland Cemetery (Halling, pers. comm.; Niklasson, pers. comm.; Eriksson, pers. comm.; Jerry Nilsson pers. comm.; Lehtimaa, pers. comm.). One reason for this may be that these plans, except for those of Tyresån Watershed and small areas of the National Urban Park, are commonly formulated on the basis of the long-term goals, and lack temporal aspects of management activity priorities at shorter, mesoterm scales.

One way of verifying if the short-term goals, manifested in practical management activities, are aligned with long-term goals, is to monitor and evaluate the management impact. Our analysis revealed that the management of the Stockholm Woodland Cemetery, the Flaten Nature Reserve, and large parts of the National Urban Park lacks programs for monitoring and evaluation, meaning that annual practical management is not evaluated against the aim and long-term goals of management. The water courses are managed separately from the rest of the watersheds, and include regular monitoring, evaluation, and management revision, e.g., in the Flaten Nature Reserve and in the National Urban Park (Lindgren, pers. comm.).

\section{Functional Scales}

In the ecosystem management criteria of functional scales, recognition of spatial and temporal scale interactions is embedded, and many of the functional mismatches result from the abovedescribed scale management. The analysis questions concerned the manager's perception of disturbances, reasons for variation in management, and identification of key ecological processes and functions. 
In all the green spaces, key ecological processes and functions are identified. For example, to sustain biodiversity in the forests, managers in the National Urban Park (Kungliga Djurgårdens Förvaltning 1993-1994), the Tyresta Forest (Matzon, pers. comm., Naturvårdsverket 1993), and the Flaten Nature Reserve (Stockholm stad 2002) leave dead wood in place. This is not the case in the Stockholm Woodland Cemetery because values other than ecological ones are given priority (Bo Olsson, pers. comm.). Another example is that managers remove shrubbery, introduce grazing, and manually remove grass on overgrown, agricultural land in the National Urban Park (Niklasson, pers. comm.) and in the Flaten Nature Reserve (Stockholm Stad 2002) to enhance plant biodiversity. It is customary within the context of Swedish nature conservation to prioritize maintenance of open landscapes, which means intensive management of shrub clearing, followed by grazing, which will normally enhance biological diversity of highly valued habitats found in the pre-industrial cultural landscapes (cf. Cousins and Eriksson 2001, Persson 2001, Vävare 2005). Several scales of biological organization are recognized in management planning, but almost all the ecological processes and functions are identified and managed at the biotope scale. This indicates an isolated view of the biotopes that ignores their potential interactions even within one management regime.

Disturbance regimes constitute one aspect of ecological dynamics that has both temporal and spatial dimensions. All the investigated management practices aim to preserve and reintroduce disturbance regimes to enhance biodiversity. A significant natural disturbance in the Tyresån Watershed is variation in water level due to rainfall and the associated hydrological dynamics. The water level is and has been regulated at several sites, and both the natural and societal systems are adapted to this artificially controlled variation (Länsstyrelsen i Stockholms län 2002b). Uncontrolled, more natural water-level fluctuations would enhance biological diversity (Nilsson et al. 1997, Nilsson and Berggren 2000, Degerman et al. 2004), but would also cause societal damage in other parts of the watershed. This implies that, even if the disturbance regime is recognized, it is impossible to abolish regulation completely. Natural thinning within forest stands, caused by disturbances such as pests, fires, and storms, is important for regeneration of pines in coniferous forests (Messier et al. 1999, Karlsson and Örlander 2004, Hille and den Ouden
2004). Although such disturbances are recognized at the Stockholm Woodland Cemetery, they are compromised by the cemetery's cultural functions (Kyrkogårdsförvaltningen 2003; Nordström, pers. comm.; Append.3). To satisfy the multipurpose functions of the area, forest thinning artificially substitutes for natural disturbances. The above examples show that the multiple purposes of these urban green spaces result in smaller margins of ecological variation and dynamics.

\section{DISCUSSION}

This empirical study revealed general characteristics concerning recognition of ecological scales in the current green-space management of the GSMA. The five study areas were intentionally selected because of their differing characteristics, which reflect the heterogeneous nature of urban landscapes. We found that mismatches existed between management practices and ecological scales to varying degrees in every location. First, several scales were recognized in management practices, but crossscale interactions were often neglected. Second, spatial and temporal meso-scales are seldom prioritized in management. Compared with hierarchical planning, it is thus obvious that the tactical scale of green-space management in the GSMA is weakened (Fig. 2).

\section{Limited Cross-scaling and Neglected Meso- scales in the GSMA}

In the studied green spaces, the managers' awareness of the importance of planning at several scales to guide management was expressed in a general multi-scale management approach. However, there was only very limited cross-scaling, indicating a limited awareness of ecosystem interconnectedness.

The need for long-term perspectives, such as those explicit in the sustainable development concept and climate change policies, has recently been acknowledged. These have been incorporated into the management plans for green spaces, but with limited connections to operational annual planning and daily practices. One reason for this is the limited recognition of temporal aspects in the management plans, which usually lack temporal priorities. Furthermore, an important temporal link that is missing in the management of these green spaces is 
Fig. 2. The main deficits in scale management of green spaces in the GSMA are neglect of meso-scales and limited recognition of cross-scale interactions.

\section{Temporal scale}

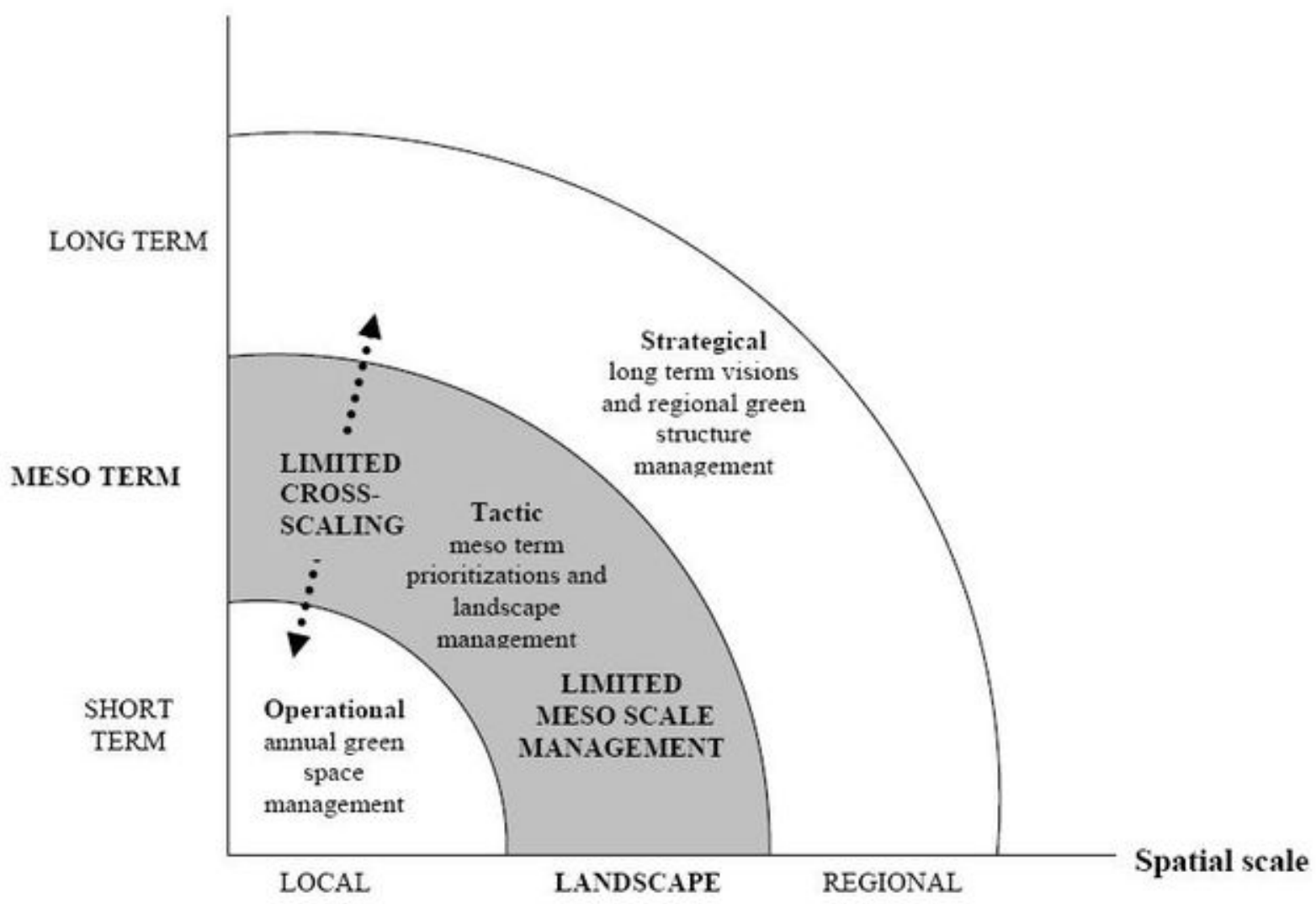

programs for monitoring and evaluating both plans and practical management.

Concerning spatial scales, most of the management plans commonly mention the importance of the GSMA regional green structure. However, the combination of management reports and interviews revealed a limited awareness of ecological crossscaling, and neglect of the interactions with the surrounding urban landscape. This was evident in the lack of communications between neighboring stakeholders. Although it is important to safeguard the dynamics within the ecological boundaries of a management area, it is vital to recognize the interconnections between adjoining and surrounding landscapes and land-use types, because they have an impact on the green space. Large areas such as the Tyresta Forest may constitute core areas for the more isolated biotopes closer to the city, but even these rich areas can be hit by devastating disturbances, e.g., fires or pest outbreaks. In such situations, connections to other green areas may be crucial for recovery (cf. Nyström and Folke 2001).

The management view of the studied green spaces as spatially isolated and temporally static not only increases their vulnerability, but also results in counter-productive activities, such as the clearing 
and grazing of land near the eutrophic lake in the Flaten Nature Reserve. Even if functional scales are to some extent recognized within local and operational management, this lack of spatial and temporal cross-scaling inhibits recognition of the ecosystem dynamics. One probable source of the limited cross-scaling is the low priority given to meso-scales, expressed in management activities that are disconnected from the surrounding landscape, with plans incapable of bridging longterm and short-term goals (Fig. 2).

\section{Scale Mismatch in Urban Landscapes}

The green spaces in this study have in common the fact that they are located in an urban context; a condition that we argue is an important contributor to the scale mismatches we found. The urban landscape is extremely heterogeneous, meaning that the spatial units are small and scattered (Hobbs 1998, Pickett et al. 2001, Alberti et al. 2003, BerlingWolff and $\mathrm{Wu} 2004$, Zhang et al. 2004). In this kind of landscape, one possible source of mismatch is the difficulty in coordinating the many subdivisions among different administrative tasks within this urban heterogeneity and matching them to an everchanging and interconnected ecological dynamic. This is exemplified in the National Urban Park and the Flaten Nature Reserve, where the watersheds are divided between different management authorities. Another clear example is the diversity of stakeholders in the National Urban Park and the limited communication among them is a clear example of how this urban heterogeneity may result in mismatched management. Furthermore, the high degree of landscape heterogeneity creates a challenging diversity already at the operational scale, manifested in the separated management of different biotope patches even within one manager's domain.

Even if the urban green spaces seem to be isolated islands in an intensively used and contrasting urban matrix, these areas interact with their surroundings, or are at least affected by it. The urban matrix may act as a source of air, light, and noise pollution, and is both a source of and barrier to flows of matter and energy (McIntyre and Hobbs 1999). But these interactions are hidden by the sharp transitions in land use, or weak and threatened ecological links to other green spaces, and are therefore probably difficult to recognize and match in management. One of the most striking deficits in scale management found in this study was the limited communication with stakeholders in the areas surrounding most of the green spaces.

Urban landscapes are changing fast, driving frequent changes in both abiotic and biotic variables, such as disturbance regimes, temperature, and species composition (Pickett et al. 2001, Zhang et al. 2004). The scale mismatch occurs when management is unable to respond to these rapid changes. In several cases, the management of the green spaces lacked programs for monitoring and evaluating that might enable more effective responses to rapid changes in the ecosystems. Overall, this pattern of scattered urban green spaces that interact with the larger, rapidly changing, urban social-ecological landscape might result in management with less opportunity for flexibility and recognition of ecological dynamics.

Within the fields of natural resource management and biodiversity conservation, there is growing recognition of the importance of ecological processes and functions, e.g., the need for disturbances such as forest fires and grazing, in maintaining biodiversity. But because a large share of the urban landscape is locked by intensive land use, there is limited or no space for allowing dynamism in management, at least not at larger scales that might have an impact outside the management boundaries. Another aspect of functional scale mismatch is that, compared with other ecosystems, urban green spaces commonly aim to satisfy multiple purposes within a small area, necessitating trade-offs, for example, between forest fires, public safety, and accessibility (Sandström et al. 2006b). In this study, examples of these trade-offs are found in the Stockholm Woodland Cemetery, where dead wood is removed from the pine forests, and in the Tyresån Watershed, where water-flow regulation is necessary. In many urban landscapes, citizens do not directly depend on locally functioning ecosystems because the support for energy, resources, and waste retention is provided by ecosystems elsewhere (Rees 1997, Folke et al. 1997). These missing connections between citizens and the urban green spaces may result in limited common understanding of ecosystem complexity and dynamics (cf. Turner et al. 2004). The recreational values may, therefore, be perceived as easier to prioritize in management than, for example, arguing for the need to introduce disturbance regimes for sustained biodiversity. A possible strategy for handling this "multipurpose 
dilemma" that is explicit in the urban context, may be zoning of urban green spaces, where different purposes are prioritized in different locations (Sandström et al. 2006b).

\section{Strategies for Scale Matching in Urban Landscapes}

The scale mismatches found in this study indicate that the investigated green spaces are viewed as static and isolated entities within the urban landscape, not as integrated elements in a larger, complex, urban social-ecological system. As scale mismatches of this kind have been shown to cause non-functional ecological networks (Angelstam et al. 2003b), it may slowly degrade the capacity of the urban ecosystems and the urban landscape as a whole to cope with future global changes. An important issue for the future sustainability of urban landscapes and regions is, therefore, to find and implement strategies that reduce or eliminate the disconnect we found in management practices between operational, tactical, and strategic scales. We suggest two complementary strategies for scale matching in urban landscapes. The first is to develop an integrative view of the whole urban socialecological landscape, and the second is to enable an integration of this view into practical management by creating adaptive governance systems.

Assuming that cities function as integrated socialecological systems, we argue that, in sustaining and developing an adaptive capacity for sustainable cities, urban landscape management must combine land-use policy with nature conservation. This is consistent with the on-going discussions within the urban planning realm about combining urban development and ecosystem preservation (cf. Ahern 1999, Arendt, 1999, Austin 2004). As the urban green areas are both affected by and affect neighboring areas independent of land use, scales must be matched through cross-scale integration of all types of urban structures into management. We argue that the urban management challenge is to view the heterogeneous nature of the city as a complex, interrelated, dynamic landscape, with multiple patch types consisting of green spaces, transportation infrastructure, and built-up areas, etc. The suggested systemic view of cities is further supported by the current discussion on the need for a more dynamic, landscape-wide, management within biodiversity conservation (Lindenmayer and Franklin 2002, Elmqvist et al. 2003, Thorell 2003,
Bengtsson et al. 2003) and the more integrated, landscape approach is also discussed as a way to reduce vulnerability in this era of global change (da Fonseca et al. 2005).

Furthermore, we believe that, even if integrated in a holistic landscape management plan, the urban landscape still provides very limited ecological flexibility and, therefore, social flexibility is extremely important in these landscapes. Thus, the second strategy is to enable an urban governance system that allows institutional cross-scaling and flexibility. The needed adaptive governance includes testing a diversity of knowledge in practical management; a diversity of institutions linked across scales; and finally, acceptance of uncertainty as a precondition in all socialecological management (Folke et al. 2005, Lebel et al. 2006). International policy documents clearly state, both explicitly and implicitly, that ecological sustainability through an ecosystem approach is an important objective (UNEP 1998, Organisation for Economic Cooperation and Development 2001). Meanwhile, diverse new tools are needed for managers and researchers alike to address the challenges of urbanization. Since the mid-1990s, long-term sustainability visions and regional green structure planning have been added to green-space management regimes. Before that, these large-scale perspectives were missing. Recently, many regional policy tools have been developed to handle these management challenges, e.g., the European Water Directive, proposing a landscape management restricted by watershed boundaries. But these tools are not adapted to the specific urban socialecological realities discussed in this paper, and furthermore, seldom address both the need for crossscaling and adaptive governance that we suggest. In an era of global urbanization as part of several global environmental changes, there is an urgent need for adaptation of existing tools, such as the Convention on Biological Diversity, to the urban context, as well as creation of new urban sustainability policy frameworks, which further requires the development of new arenas for governance. Two examples of possible urban landscape management tools that may provide these kinds of arenas are: 1) the biosphere reserve concept of the UNESCO Man and the Biosphere Program and 2) the concept of Model Forests in urban landscapes.

Within a joint program run by Columbia University, the limits and possibilities of the biosphere reserve concept, used within the UNESCO Man and the 
Biosphere Program, have been tested in several case studies that also include urban landscapes, e.g., Istanbul, Cape Town, and New York (AlfsenNorodom and Lane 2002). The biosphere reserve concept in use includes three functions: 1) conserving biodiversity at all levels of biological organization, 2) fostering economic and human development that is socioculturally and ecologically sustainable, and 3) providing support for research, monitoring, education, and information exchange (UNESCO 1995). The second important aspect of this concept is the strategy of zoning, creating core areas, buffer zones, and development areas with different restrictions and priorities of values to be promoted (UNESCO 1995). The urban case studies showed that the biosphere concept has the potential to provide a platform and a set of incentives for dialogue and reconciliation of conflicting urban interests, and is also applicable across disciplines, ownership types, and institutional boundaries (Alfsen-Norodom et al. 2004). As the aim of a biosphere area is to create areas large enough to satisfy needs of both preservation and development within the same landscape management area, it promises to address both our suggestions. Many cities, including the GSMA, are situated in forested landscapes. Similar to the biosphere concept is the Model Forest concept developed in Canada. This program was extended internationally in 1992, when the International Model Forest Network was initiated (Besseau et al. 2002). Model forests are used to implement sustainable management of forest resources by building partnerships with stakeholders in a given region. Some model forests include suburban and urban landscapes, e.g., the Eastern Ontario Model Forest encompasses forest, urban, and agricultural land, and the Reventazón Model Forest in Costa Rica provides $25 \%$ of the San José metropolitan area's drinking water. These two concepts are examples of tools that might be flexible enough to initiate the process of urban landscape management as we suggest.

Finally, the view of green spaces as static and isolated from the urban matrix that we found in this study may simply be a symptom of more consistent scale mismatches throughout urban landscapes. We hope that the trend toward incorporating multiple scales into management will help managers recognize meso-scales as being as important as long-term, regional and short-term, local scales. By recognizing meso-scales, managers can introduce a missing level of tactical planning that could connect strategic and operational levels in both time and space. The high heterogeneity of urban systems is unavoidable, and produces intensive interactions between every patch and its surroundings at all levels of scale. By taking advantage of the huge challenges presented by urban systems, of which only some are discussed here, we find that there are opportunities to learn and develop more flexible adaptive management policies that are more in tune with the dynamic nature of social-ecological landscapes.

Responses to this article can be read online at:

http://www.ecologyandsociety.org/vol11/iss2/art16/responses/

\section{Acknowledgments:}

We gratefully acknowledge the key informants who provided information for this study, as well as their time and engagement: Göran Andersson, Rebecka Axelsson, Rolf G. Eriksson, Rune Eriksson, Joakim Främborg, Claes Halling, Göran Karlström, Erkki Lehtimaa, Per Linder, Gunilla Lindgren, Curt Matzon, Henrik Niklasson, Helen Nilsson, Jerry Nilsson, Leif Nordström, Bo Olsson, Börje Olsson, Hedvig Rönnbäck, Bo Wallström, and Maria Westerdahl. We would also like to thank Erik Andersson, Hoski Schaafsma, and Stephan Barthel for comments on previous versions of this manuscript. Finally, we want to thank the reviewers for inspiring and valuable comments.

\section{LITERATURE CITED}

Ahern, J. 1999. Spatial concepts, planning strategies and future scenarios: a framework for integrating landscape ecology and landscape planning. Pages 175-201 in J. M. Klopatek and R. H. Gardner, editors. Landscape ecological analysis: issues and applications. Springer-Verlag, New York, New York, USA.

Alberti, M., J. M. Marzluff, E. Schulenberger, G. Bradley, C. Ryan, and C. Zumbrunnen. 2003. Integrating humans into ecology: opportunities and challenges for studying urban ecosystems. BioScience 53:1169-1179.

Alfsen-Norodom C., and B. D. Lane. 2002. Global knowledge networking for site specific strategies: 
the international conference on biodiversity and society. Environmental Science and Policy 5:3-8.

Alfsen-Norodom, C., B. D. Lane, and M. Corry, editors. 2004. Urban biosphere and the society. Partnerships of cities. Annals of the New York Academy of Sciences 1023:1-334.

Andersson, E. 2006. Urban landscapes and sustainable cities. Ecology and Society 11(1):34. [online] URL: http://www.ecologyandsociety.org/vol11/ iss1/art34/.

Angelstam, P. 2003. Reconciling the linkages of land management with natural disturbance regimes to maintain forest biodiversity in Europe. Pages 193-226 in J. A. Bissonette and I. Storch, editors. Landscape ecology and resource management: linking theory with practice. Island Press, Washington, D.C., USA.

Angelstam, P., and L.Andersson. 2001. Estimates of the needs for forest reserves in Sweden. Scandinavian Journal of Forest Research Supplement 3:38-51.

Angelstam, P., G. Mikusinski, B.-I. Rönnbäck,A. Östman, M. Lazdinis, J.-M. Roberge, W. Arnberg, and J. Olsson. 2003a. Two-dimensional gap analysis: a tool for efficient conservation planning and biodiversity policy implementation. Ambio 33:527-534.

Angelstam, P., R. Bütler, M. Lazdinis, G. Mikusinski, and J.-M. Roberge. 2003b. Habitat thresholds for focal species at multiple scales and forest biodiversity conservation-dead wood as an example. Annales Zoologici Fennici 40:473-482.

Angelstam, P., M. Dönz-Breuss, and J.-M. Roberge, editors. 2004. Targets and tools for the maintenance of forest biodiversity. Ecological Bulletins 51:11-24.

Angelstam, P., J.-M. Roberge, T. Ek, and L. Laestadius. 2005. Data and tools for conservation, management, and restoration of forest ecosystems at multiple scales. Pages 269-283 in J. A. Stanturf and P. Madsen, editors. Restoration of boreal and temperate forests. Taylor and Francis, London, UK.

Arendt, R. G. 1999. Growing greener: putting conservation into local plans and ordinances. Island Press, Washington, D.C., USA.
Austin, M. E. 2004. Resident perspectives of the open space conservation subdivision in Hamburg Township, Michigan. Landscape and Urban Planning 69:245-253.

Barthel, S., J. Colding, T. Elmqvist, and C. Folke. 2005. History and local management of a biodiversity-rich, urban, cultural landscape. Ecology and Society 10(2):7. [online] URL: http:// www.ecologyandsociety.org/vol10/iss2/art7.

Beckett K. P., P. H. Freer-Smith, and G. Taylor. 1998. Urban woodlands: their role in reducing the effects of particulate pollution. Environmental Pollution 99:347-360.

Bengtsson, J., P. Angelstam, T. Elmqvist, U. Emanuelsson, C. Folke, M. Ihse, F. Moberg, and M. Nyström. 2003. Reserves, resilience and dynamic landscapes. Ambio 32:389-396.

Berglund, B., T. Kihlman, W. Kropp, and E. Öhrström. 2004. Soundscape support to health. Final report, phase I. Chalmers, Göteborg, Sweden. (Online.) URL: http://www.soundscape.nu/finalrep ort en.asp.

Berkowitz, A. R., C. H. Nilon, and K. S. Hollweg, editors. 2003. Understanding urban ecosystems. A new frontier for science and education. SpringerVerlag Inc. New York, New York, USA.

Berling-Wolff, S., and J. Wu. 2004. Modeling urban landscape dynamics: a case study in Phoenix, USA. Urban Ecosystems 7:215-240.

Besseau, P., K. Dansou, and F. Johnson. 2002. The international model forest network (IMFN): elements of success. The Forestry Chronicle 78:648-654.

Bolund, P., and S. Hunhammar. 1999. Ecosystem services in urban areas. Ecological Economics 29:293-301.

Borgström, S. 2003. Management of urban green areas in the Stockholm County. Thesis (report 2003:18), Department of Systems Ecology, Stockholm University, Stockholm, Sweden. [online] URL: http://www.urec.info.

Bratt, P. 1998. Forntid $i$ ny dager. Arkeologi $i$ Stockholmstrakten. Raster Förlag, Stockholm, 
Sweden.

Briggs, S. V. 2001. Linking ecological scales and institutional frameworks for landscape rehabilitation. Ecological Management and Restoration 2:28-35.

Brown, K. 2003. Integrating conservation and development: a case of institutional misfit. Frontiers in Ecology 1:479-487.

Carreiro, M. M., and C. E. Tripler. 2005. Forest remnants along urban-rural gradients: examining their potential for global change research. Ecosystems 8:568-582

Carpenter, S. R., and L. Gunderson. 2001. Coping with collapse: ecological and social dynamics in ecosystem management. BioScience 51:451-457.

Christensen, N. L., A. M. Bartuska, J. H. Brown, S. Carpenter, C. D'Antonio, R. Francis, J. F. Franklin, J. A. MacMahon, R. F. Noss, D. J. Parsons, C. H. Peterson, M. G. Turner, and R. G. Woodmansee. 1996. The report of the Ecological Society of America Committee on the scentific basis for ecosystem management. Ecological Applications 6:665-691.

Cleveland, C., R. Costanza, T. Eggertsson, L. Fortmann, B. Low, M. McKean, E. Ostrom, J. Wilson, and O. Young. 1996. A framework for modelling the linkages between ecosystems and human systems. Beijer Discussion Paper No. 76. Beijer International Institute for Ecological Economics, Stockholm, Sweden.

Collins, J. P., A. Kinzig, N. B. Grimm, W. F. Fagan, D. Hope, J. Wu, and E. T. Borer. 2000. A new urban ecology. American Scientist 88:416425 .

Cousins S.A., and O. Eriksson. 2001. Plant species occurrences in a rural hemiboreal landscape: effects of remnant habitats, site history, topography and soil. Ecography 24:461-469.

Cumming G. S., D. H. M. Cumming, and C. L. Redman. 2006. Scale mismatches in socialecological systems: causes, consequences, and solutions. Ecology and Society 11(1):14. [online] URL: http://www.ecologyandsociety.org/vol11/iss1/ art14/.

da Fonseca, G. A. B., W. Sechrest, and J.
Oglethorpe. 2005. Managing the matrix. Pages 346- 358 in T. E. Lovejoy and L. Hannah, editors. Climate change and biodiversity. Yale University Press, London, UK.

Dale, V. H., S. Brown, R. A. Haeuber, N. T. Hobbs, N. Huntly, R. J. Naiman, W. E. Riebsame, M. G. Turner, and T. J. Valone. 2000. Ecological principles and guidelines for managing the use of land. Ecological Applications 10:639-670.

Degerman, E., B. Sers, J. Törnblom, and P. Angelstam. 2004. Large woody debris and brown trout in small forest streams - towards targets for assessment and management of riparian landscapes. Ecological Bulletins 51:233-239.

Elmqvist, T., C. Folke, M. Nyström, G. Peterson, J. Bengtsson, B. Walker, and J. Norberg. 2003. Response diversity, ecosystem change and resilience. Frontiers in Ecology and the Environment 1:488-494.

Elmqvist, T., J. Colding, S. Barthel, S. Borgström, A. Duit, J. Lundberg, A. E. K. Ahrne, H. Ernstson, C. Folke, and J. Bengtsson. 2004. The dynamics of social-ecological systems in urban landscapes. Stockholm and the National Urban Park, Sweden. Annals of the New York Academy of Sciences 1023:308-322.

Engstrom, R. T., S. Gilbert, M. L. Hunter, D. Merriwether, G. J. Nowacki, and P. Spencer. 1999. Practical applications of disturbance ecology to natural resource management. Pages 313-329 in R. C. Szaro, N. C. Johnson, W. T. Sexton, and A. J., Malk, editors. Ecological stewardship. A common reference for ecosystem management. Vol. 2. Elsevier Science, Oxford, UK.

Folke, C., А. Jansson, J. Larsson, and R. Costanza. 1997. Ecosystem appropriation by cities. Ambio 26:167-172.

Folke, C., L. Pritchard, Jr., F. Berkes, J. Colding, and U. Svedin. 1998. The problem of fit between ecosystems and institutions. IHDP Working Papers IHDP Working Papers No. 2. International Human Dimensions Programme on Global Environmental Change (IHDP) Bonn, Germany.

Folke, C., T. Hahn, P. Olsson, and J. Norberg. 2005. Adaptive governance of social-ecological systems. Annual Review of Environmental 
Resources 30:441-473.

Grahn, P., and J. Ottosson. 1998. Utemiljöns betydelse för äldre med stort vårdbehov "Med ögon känsliga för grönt”. Stad och Land nr 44. Movium, Alnarp, Sweden.

Grimm, N. B., J. M. Grove, S. T. A. Pickett, and C. Redman. 2000. Integrated approaches to longterm studies of urban ecological systems. BioScience 50:571-584.

Grimm, N. B., and C. Redman. 2004. Approaches to study the urban ecosystems: the case of Central Arizona - Phoenix. Urban Ecosystems 7:199-213.

Grumbine, R. E. 1994. What is ecosystem management? Conservation Biology 8:27-38.

Gunderson, L. H., C. S. Holling, and S. S. Light, editors. 1995. Barriers and bridges to the renewal of ecosystems and institutions. Columbia University Press, New York, New York, USA.

Haufler, J. B., T. Crow, and D. Wilcove. 1999. Scale considerations for ecosystem management. Pages 331-342 in R. C. Szaro, N. C. Johnson, W. T. Sexton, and A. J., Malk, editors. Ecological stewardship. A common reference for ecosystem management. Vol 2. Elsevier Science, Oxford, UK.

Higman, S., S. Bass, N. Judd, J. Mayers, and R. Nussbaum. 1999. The sustainable forestry handbook. Earthscan Publications Ltd, London, UK.

Hille, M., and J. den Ouden. 2004. Improved recruitment and early growth of Scots pine (Pinus sylvestris L.) seedlings after fire and soil scarification. European Journal of Forest Research 123:213-218.

Hobbs, R. J. 1998. Managing ecological systems and processes. Pages 459-484 in D. L. Peterson and V. T. Parker, editors. Ecological scale. Theory and applications. Columbia University Press, New York, New York, USA.

Holling, C. S. 1992. Cross-scale morphology, geometry and dynamics of ecosystems. Ecological Monographs 62:447-502.

Holling, C. S. 1995. Sustainability: the cross-scale dimension. Pages 65-87 in M. Munasinghe and W.
Shearer, editors. Defining and measuring sustainability. The biogeophysical dimensions. The International Bank for Reconstruction and Development/The World Bank, Washington, D.C., USA.

Holling, C. S. 2001. Understanding the complexity of economic, ecological and social systems. Ecosystems 4:390-405.

Holling, C. S., and G. K. Meffe. 1996. Command and control and the pathology of natural resource management. Conservation Biology 10:328-337.

Holling, C. S., L. H. Gunderson, and G. D. Peterson. 2002. Sustainability and panarchies. Pages 63-102 in L. H. Gunderson and C. S. Holling, editors. Panarchy. Understanding transformations in human and natural systems. Island Press, Washington, D.C., USA.

Jansson, Å., and P. Nohrstedt. 2001. Carbon sinks and human freshwater dependence in Stockholm County. Ecological Economics 39:361-370.

Jonsson, B., J. Jacobsson, and H. Kallur. 1993. The forest management planning package. Theory and application. Studia Forestalia Suecica 189.

Karlsson, C., and G. Örlander. 2004. Naturlig föryngring av tall. Skogsstyrelsens Rapporter 4. Skogsstyrelsens förlag, Jönköping, Sweden.

Kinzig, A., and J. M. Grove. 2001. Urbansuburban ecology. Encyclopedia of Biodiversity 5:733-745.

Kungliga Djurgårdens förvaltning. 1993-1994. Skötselplan omfattande Norra och Södra Djurgården. Stockholm, Sweden.

Kyrkogårdsförvaltningen. 2003. Förfrågningsunderlag. Grav och grönyteskötsel på kyrkogårdsmarkskogskyrkogården, Enskede. Stockholm, Sweden.

Länsstyrelsen i Stockholms län. 1996. Tyresån, mål och åtgärder. Stockholm, Sweden.

Länsstyrelsen i Stockholms län. 2002a. Förslag till verksamhetsplanering 2002-2006. Working material, unpublished. Stockholm, Sweden.

Länsstyrelsen i Stockholms län. 2002b. För renare vatten i Tyresån. Brochure. Stockholm, Sweden. 
Länsstyrelsen i Stockholms län. 2003. Aldrig långt till naturen. Program för skydd av tätortsnära natur $i$ Stockholmsregionen. Rapport 2003:20, Länsstyrelsen i Stockholms län, Stockholm, Sweden.

Lazdinis, M., and P. Angelstam. 2004. Connecting social and ecological systems: an integrated toolbox for hierarchical evaluation of biodiversity policy implementation. Ecological Bulletins 51:385-400.

Lebel, L., J. M. Anderies, B. Campbell, C. Folke, S. Hatfield-Dodds, T. P. Hughes, and J. Wilson. 2006. Governance and the capacity to manage resilience in regional social-ecological systems. Ecology and Society 11(1):19. [online] URL: http:/ /www.ecologyandsociety.org/vol11/iss1/art19/

Lee, K. N. 1993. Greed, scale mismatch and learning. Ecological Applications 3:560-564.

Levin, S. 1999. Fragile dominion. Complexity and the commons. Perseus Publishing, Cambridge, Massashusetts, USA.

Levin, S. 2000. Multiple scales and the maintenance of biodiversity. Ecosystems 3:498-506.

Lindenmayer, D. B., and J. F. Franklin, editors. 2002. Conserving forest biodiversity: a comprehensive multiscaled approach. Island Press, Washington, D. C., USA.

Lindholm, A., and J. Kukka. 2001a. Flatens naturreservat-analys av den historiska markanvändningen. Stockholm, Sweden. (Unpublished material.)

Lindholm, A., and J. Kukka J. 2001b. Det äldre kulturlandskapets naturvärden vid Flatens naturreservat - bakgrund till skötselplan. Stockholm, Sweden. (Unpublished material.)

Lõhmus, A., K. Kohv, A. Palo, and K. Viilma. 2004. Loss of old-growth, and the minimum need for strictly protected forests in Estonia. Ecological Bulletins 51:401-411.

Lugo, A. E., J. S. Baron, T. P. Frost, T. W. Cundy, and P. Dittberner. 1999. Ecosystem processes and functioning. Pages 219-250 in R. C. Szaro, N. C. Johnson, W. T. Sexton, and A. J., Malk, editors. Ecological stewardship. A common reference for ecosystem management. Vol. 2. Elsevier Science, Oxford, UK.

Lundberg, J., and F. Moberg. 2003. Mobile link organisms and ecosystem functioning: implications for ecosystem resilience and management. Ecosystems 6:87-98.

McIntyre, S., and R. Hobbs. 1999. A framework for conceptualizing human effects on landscapes and its relevance to management and research models. Conservation Biology 13:1282-1292.

McPherson, E. G., D. Nowak, G. Heisler, S. Grimmond, C. Souch, R. Grant, and R. Rowntree. 1997. Quantifying urban forest structure, function and value; the Chicago urban forest climate project. Urban Ecosystems 1:49-61.

Messier, C., R. Doucet, J.-C. Ruel, Y. Claveau, C. Kelly, and M. J. Lechowicz. 1999. Functional ecology of advance regeneration in relation to light in boreal forests. Canadian Journal of Forest Research 29:812-823.

Naturvårdsverket. 1993. Tyresta Nationalpark. Skötselplan med föreskrifter. Allmänna råd 93.8. Naturvårdsverket, Stockholm, Sweden.

Nilsson, C., R. Jansson, and U. Zinko. 1997. Longterm responses of river-margin vegetation to waterlevel regulations. Science 276:798-800.

Nilsson, C., and K. Berggren. 2000. Alteration of riparian ecosystems caused by river regulation. Bioscience 50:783-792.

Nyström, M., and C. Folke. 2001. Spatial resilience of coral reefs. Ecosystems 4:406-417.

Organisation for Economic Cooperation and Development (OECD). 2001. Policies to enhance sustainable development. Meeting of the OECD Council at the ministerial level. OECD Publications, Paris, France.

Patton, M. Q.1987. How to use qualitative methods in evaluation. Sage Publications, London, UK.

Persson, C. 2001. Ängs- och hagmarker $i$ Stockholms län. Underlagsmaterial 08, Länsstyrelsen i Stockholms län, Stockholm, Sweden.

Peterson, G. D., C. R. Allen, and C. S. Holling. 
1998. Ecological resilience, biodiversity and scale. Ecosystems 1:6-18.

Pickett, S. T. A., W. R. Burch, Jr., S. E. Dalton, T. W. Foresman, J. M. Grove, and R. Rowntree. 1997. A conceptual framework for the study of human ecosystems in urban areas. Urban Ecosytems 1:185-199.

Pickett, S. T. A., M. L.Cadenasso, J. M. Grove, C. H. Nilon, R. V. Pouyat, W. C. Zipperer, and R. Costanza. 2001. Urban ecological systems: linking terrestrial ecological, physical and socioeconomic components of metropolitan areas. Annual Review of Ecological Systems 32:127-157.

Raivio, S., E. Normark, B. Pettersson, and P. Salpakiivi-Salomaa. 2001. Science and the management of boreal forest biodiversity-forest industries' view. Scandinavian Journal of Forest Research Supplement 3:99-104.

Rees, W. E. 1997. Urban ecosystems: the human dimension. Urban Ecosystems 1:63-75.

Roberge, J.-M., and P. Angelstam. 2004. Usefulness of the umbrella species concept as a conservation tool. Conservation Biology 18:76-85.

Regionplane- och trafikkontoret (RTK). 2001. Regional utvecklingsplan 2001 för Stockholms regionen. Regionplane- och trafikkontoret i Stockholm, Stockholm, Sweden.

Sandström, U. G., P. Angelstam, and A. Khakee. 2006a. Urban comprehensive planning_-identifying barriers for the maintenance of functional habitat networks. Landscape and Urban Planning 75:4357.

Sandström, U. G., P. Angelstam, and G. Mikusinski. 2006b. Ecological diversity of birds in relation to the structure of urban green space. Landscape and Urban Planning 77:39-53.

Saunders, D. A., and S. V. Briggs. 2002. Nature grows in straight lines-or does she? What are the consequences of the mismatch between humanimposed linear boundaries and ecosystem boundaries? An Australian example. Landscape and Urban Planning 61:71-82.

Scheffer, M., S. R. Carpenter, J. Foley, C. Folke, and B. Walker. 2001. Catastrophic shifts in ecosystems. Nature 413:591-596.

Schwartz, M. W., editor. 1997. Conservation in highly fragmented landscapes. Chapman and Hall, New York, New York, USA.

Scott, J. M., F. Davis, B. Csuti, R. Noss, B. Butterfield, C. Groves, H. Anderson, S. Caicco, T. Edwards, J. Ulliman, and R. G. Wright.1993. Gap analysis: a geographic approach to protection of biological diversity. Wildlife Monographs 123:141.

Scrimgeour, G. J., and S. Kendall. 2002. Consequences of livestock grazing on water quality and benthic algal biomass in a Canadian natural grassland plateau. Environmental Management 29:824-844.

Slocombe, D. S. 1993. Implementing ecosystembased management. BioScience 43:612.

Slocombe, D. S. 1998. Defining goals and critera for ecosystem-based management. Environmental Management 22:483-493.

Stanturf, J. A., and P. Madsen. 2005. Restoration of boreal and temperate forests. CRC Press, Boca Raton, Florida, USA.

Statistiska Centralbyrån (SCB). 1993. Statistiska Meddelanden Na 12 SM 9301 (Green areas within and in the vicinity of urban settlements). SCB, Stockholm, Sweden.

SCB. 2002. Statistiska Meddelanden MI 38 SM 0101, Tätorter 2000. SCB, Stockholm, Sweden.

SCB. 2005. Statistiska Meddelanden MI 0810, Tätorter, arealer och befolkning. SCB, Stockholm, Sweden.

Stenhouse, R. N. 2004. Fragmentation and internal disturbance of native vegetation reserves in the Perth metropolitan area, Western Australia. Landscape and Urban Planning 68:389-401.

Stockholm stad. 2002. Flatens naturreservatförslag till beslut. Unpublished material. Stockholm, Sweden.

Szaro, R., P. Angelstam, and D. Sheil. 2005. Information needs for ecosystem forestry. Pages 31-26 in J. A. Sayer and S. Maginnis, editors. 
Forests in landscapes. Ecosystem approaches to sustainability. Earthscan, London, UK.

Thorell, M. 2003. Forest conservation strategy in southern Sweden: the role of small reserves and buffer zones. University of Göteborg, Göteborg, Sweden.

Turner, M. G., R. H. Gardner,and R.V. O'Neill. 2001. Landscape ecology in theory and practice. Pattern and process. Pages 265-280. Springer, New York, New York, USA.

Turner, W. R., T. Nakamura, and M. Dinetti. 2004. Global urbanization and the separation of humans from nature. BioScience 54:585-590.

Ulrich, R. 1984. View from a window may influence recovery from surgery. Science 224:420421.

United Nations (U.N.). 2004. World urbanization prospects: the 2003 revision. U.N. Department of Economic and Social Affairs/Population Division. [online] URL: http://www.un.org/esa/population/pu blications/wup2003/2003WUPHighlights.pdf.

UNEP. 1998. Report of the Workshop on the Ecosystem Approach. Proceedings from the 4th meeting of Conference of the Parties to the Convention on Biological Diversity, Lilongwe. 2628 January 1998, Bratislava, Slovakia.

UNESCO. 1995. The Seville strategy for biosphere reserves. [online] URL: http://www.unesco.org/mab/ doc/Strategy.pdf.

Vandruff, L. W., D. L. Leedy, and F. W. Sterns. 1995. Urban wildlife and human well-being. Pages 203-212 in H. Sukopp, M. Numata, and A. Hube, editors. Urban ecology as the basis of urban planning. SPB Academic Publishing, Amsterdam, The Netherlands.

Weintraub, A., and A. Cholaky. 1991. A hierarchical approach to forestry planning. Forest Science 37:439-460.

Westerdahl, M. 1995. Skogskyrkogården $i$ Stockholm. Vegetationsinventering med förslag till åtgärder. VBB Samhällsbyggnad, Stockholm, Sweden.

White, P. S., J. Harrod, W. H. Romme, and J. Betancourt. 1999. Disturbance and temporal dynamics. Pages 281-312 in R. C. Szaro, N. C. Johnson, W. T. Sexton, and A. J., Malk, editors. Ecosystem management for sustainability. Principles and Practices illustated by regional biosphere reserve cooperation. Levis Publishers, Boston, Massachusetts, USA.

Wilson, J. A., J. M. Acheson, M. Metcalf, and P. Kleban. 1994. Chaos, complexity and community management of fisheries. Marine Policy 18:291305.

Wilson, J., B. Low, R. Costanza, and E. Ostrom. 1999. Scale misperceptions and the spatial dynamics of a social-ecological system. Ecological Economics 31:243-257.

Wirén, L. 2002. Dynamik i urbana nätverk- sociala och ekologiska perspektiv på förvaltningen av Nationalstadsparken i Stockholm. Degree project 2002:10, Department of Systems Ecology, Stockholm University, Stockholm, Sweden.

Vävare, S. 2005. Odlingslandskap i förändring. Naturvårdsverkets rapport 5420. Naturvårdsverket, Stockholm, Sweden.

Yaffee, S. L. 1999. Three faces of ecosystem management. Conservation Biology 13:713-725.

Yang, J., J. McBride, J. Zhou, and Z. Sun. 2005. The urban forest in Beijing and its role in air pollution reduction. Urban Forestry and Urban Greening 3:65-78.

Young, C. H., and P. J. Jarvis. 2001. Measuring urban habitat fragmentation: an example from the Black Country, UK. Landscape Ecology 16:643658.

Young, O. R. 2002. The institutional dimensions of environmental change. Fit, interplay and scale. The MIT press, Cambridge, Massachusetts, USA.

Young, O. R. 2003. Environmental governance: the role of institutions in causing and confronting environmental problems. International Environmental Agreements: Politics, Law and Economics 3:377393.

Zhang L., W. Jianping, Z. Yu, and S. Jiong. 2004. A GIS-based gradient analysis of urban landscape pattern of Shanghai metropolitan area, China. Landscape and Urban Planning 69:1-16. 


\section{APPENDIX 1. Description of the Greater Stockholm Metropolitan Area, GSMA}

The Swedish population is highly urbanized with $84 \%$ of the total population living in urban landscapes (SCB 2002). This process of increasing urbanization in Sweden follows the general global trend, but unlike the explosive growth of urban landscapes seen in some areas of the world, urban growth in Sweden is taking place at a moderate rate. The increased urbanization is also increasing the degree of fragmentation and isolation of green spaces. As a response, the Swedish Government has commissioned the regional city authorities in Sweden's three largest cities to coordinate regional programs for urban nature conservation. One of the three is theGreater Stockholm Metropolitan Area (GSMA, Fig. 1), which is the biggest population center in Sweden, with 1.2 million inhabitants (SCB 2002). The population of Stockholm County totals 1.8 million people and is estimated to grow by approximately 20 000 new inhabitants each year, mainly on the outskirts of the GSMA (RTF 2001). The population density in the GSMA is approximately 2500 inhabitants $/ \mathrm{km}^{2}$, compared with 14 inhabitants $/ \mathrm{km}^{2}$ in the rural parts of the Stockholm County (SCB 2002), and a total average population density in Sweden of 22 inhabitants $/ \mathrm{km}^{2}$. In Stockholm County, 7-8\% of green spaces have been developed over the last decades of the $20^{\text {th }}$ century (SCB 1993). In recognizing this decline, the recent urban nature conservation program proposes 71 new nature reserves by 2013 in or close to the GSMA (Länsstyrelsen i Stockholms län 2003).

The GSMA is situated in a landscape of rolling hills and valleys that, to a large extent, is shaped by the last glaciation period 10000 years ago, and the subsequent isostatic rebound that has raised the land from the sea. This has increased the land available for human use, and this, coupled with a steady increase in population, has increased human land uses since that time (Bratt 1998). The hills are partly covered with shallow moraine/glacial till, vegetated mainly by Scots pine (Pinus sylvestris) and weedy shrubs (e.g., heather (Calluna vulgaris) and lingonberry (Vaccinium vitis-idaea)); on the lower slopes, the sediments are deeper and spruce (Picea abies) trees dominate; the valley bottoms are covered with lush vegetation of deciduous tree species, communities dominated by, e.g., birch (Betula spp.), aspen (Populus tremula), maple (Acer platanoides), ash (Fraxinus excelsior), linden (Tilia cordata), and oak (Quercus robur). 
APPENDIX 2. Data sources for analysis (Table 2)

\section{List of management documents}

Akademiska hus AB. 1998. Markskötsel-förfrågningsunderlag funktionsansvar. Skötsel och underhållsentreprenad av grönytor och vägar mm inom Frescatiområdet Stockholms universitet. 1998.06.15. Stockholm, Sweden.

Bråvander, L. G., and R. Jacobsson 2002. Förslag till arbetsplan för skötselplan för ekoparken. Stockholm, Sweden.

Grundsten C. 2001. Nationalparken nära Stockholm. Tyresta. Naturvårdsverket förlag, Stockholm, Sweden.

Herdin C. 2002. Nationalstadsparkens ekpopulation- skötsel och förvaltning från 1600-talet till nutid. Degree project at the Institution for System Ecology at Stockholm University. Stockholm, Sweden.

Kungliga Djurgårdens förvaltning. 1993-4. Skötselplan omfattande Norra och Södra Djurgården . Stockholm, Sweden.

Kungliga Djurgårdens förvaltning. 1995. Skogsskötselplan Djurgården. Stockholm, Sweden.

Kyrkogårdsförvaltningen. 2001. Verksamhet och statistik 2001. Brochure. Stockholm, Sweden.

Kyrkogårdsförvaltningen. 2003. Förfrågningsunderlag. Grav och grönyteskötsel på kyrkogårdsmarkskogskyrkogården, Enskede. Stockholm, Sweden.

Lindholm, A., and J. Kukka. 2001:1. Flatens naturreservat - analys av den historiska markanvändningen. Stockholm, Sweden. Unpublished material.

Lindholm, A., and J. Kukka J. 2001:2. Det äldre kulturlandskapets naturvärden vid Flatens naturreservat - bakgrund till skötselplan. Stockholm, Sweden. Unpublished material.

Länsstyrelsen i Stockholms län. 1993. Skötselplan Naturreservatet Tyresta. Haninge och Tyresö kommuner. Länsstryelsen, Stockholm, Sweden.

Länsstyrelsen i Stockholms län. 1996:1. Tyresån, mål och åtgärder. Stockholm, Sweden.

Länsstyrelsen i Stockholms län. 1996:2. Samordningsuppdraget om Nationalstadsparken. Rapport 1996:2. Planenheten, Stockholm, Sweden.

Länsstyrelsen i Stockholms län. 1999. Nationalstadsparken. Mål och riktlinjer för skötsel av park och natur. Underlagsmaterial 1999:18. Stockholm, Sweden.

Länsstyrelsen i Stockholms län. 2001. Igelbäcken. Biotopkartering år 2000. Rapport 2001:14. Stockholm, Sweden.

Länsstyrelsen i Stockholms län. 2002:1. Förslag till verksamhetsplanering 2002-2006. Working material, unpublished. Stockholm, Sweden.

Länsstyrelsen i Stockholms län. 2002:2. För renare vatten i Tyresån. Brochure. Stockholm, Sweden.

Länsstyrelsen i Stockholms län. 2002:3. Resultat och kommentarer till enkät gällande utvärdering av 
Samverkansgruppen för Nationalstadsparken. Unpublished work material. Stockholm, Sweden.

Magnusson L. 1993. Trollskogen Tyresta-Åva. Naturvårdsverket, Stockholm, Sweden.

Naturvårdsverket. 1993. Tyresta Nationalpark. Skötselplan med föreskrifter. Allmänna råd 93.8. Naturvårdsverket, Stockholm, Sweden.

Naturvårdsverket. 1997. Nationalpark i Stokholms län Tyresta. Broshure. Stockholm, Sweden.

Riksantikvarieämbetet. 2002. Våra svenska världsarv. Brochure. Stockholm, Sweden.

Samfundet S:t Erik Stockholm. 1995. Ekoparken. Nationalstadsparken Ulriksdal - Haga Brunnsviken - Djurgården. S:t Eriks årsbok 1995. Samfundet S:t Erik, Stockholm, Sweden.

Solna stad, Stockholms fritidsförvaltning. 1992. Naturvårdens intressen i området Ulriksdal, HagaBrunnsviken, norra och södra Djurgården. Solna, Sweden.

Solna stad. 1997:1. Samrådsförslag januari 1997. Fördjupad översiktsplan för Nationalstadsparken. Allmän del. Nationalstadsparken som helhet. Solna, Sweden.

Solna stad. 1997:2. Samrådsförslag januari 1997. Fördjupad översiktsplan för Nationalstadsparken. Särskild del. Nationalstadsparken inom Solna. Solna, Sweden.

Solna stad. 1999:1. Vårdplan för Tivoliområdet. Del 1 Historik, skyddsvärden och allmänna riktlinjer. Solna, Sweden.

Solna stad. 1999:2. Vårdplan för tivoliområdet. Del 2 Delområdesbeskrivningar och skötselföreskrifter. Solna, Sweden.

Stiftelsen Tyrestaskogen. 1993. Stadgar. Stiftelsen Tyrestaskogen. Stockholm, Sweden.

Stiftelsen Tyrestaskogen. 2000. Storbranden i Tyresta in Tyresta fakta no 4:2000. Stockholm, Sweden.

Stiftelsen Tyrestaskogen. 2001:1. Verksamhetsplan och budget 2001. Stiftelsen Tyrestaskogen, Stockholm, Sweden.

Stiftelsen Tyrestaskogen. 2001:2. Verksamhetsberättelse 2001. Stiftelsen Tyrestaskogen, Stockholm, Sweden.

Stiftelsen Tyrestaskogen. 2002. Verksamhetsplan och budget 2002. Stiftelsen Tyrestaskogen, Stockholm, Sweden.

Stockholm stad GFK. 2001. Detaljerad skötsel vid Flatens Naturreservat. Unpublished material. Stockholm, Sweden.

Stockholm stad. 1994. Vattenprogram för Stockholm- sjöar och vattendrag. Miljöförvaltningen, Stockholm stad, Stockholm, Sweden.

Stockholm stad. 1997. Nationalstadsparkens ekologiska struktur. Stadsbyggnadskontoret, Stockholm stad, Stockholm, Sweden.

Stockholm stad. 1999. Översiktsplan 1999 Stockholm. Stadsbyggnadskontoret, Stockholm stad, Stockholm, Sweden.

Stockholm stad. 2002. Flatens naturreservat-förslag till beslut. Unpublished material. Stockholm, Sweden. 
Stockholm Vatten AB. 2000. Tillståndet $i$ sjön Flaten. Planerade åtgärder och deras effekter på miljön. Report no MV00048. Stockholm, Sweden.

Westerdahl M. 1991. Skogskyrkogården. Tallum genom tiden, historik, mål och åtgärdsprogram för skogskyrkogårdens tallbestånd. Stad och land no 99/1991. Movium, Alnarp, Sweden.

Westerdahl M. 1995. Skogskyrkogården i Stockholm. Vegetationsinventering med förslag till åtgärder. VBB Samhällsbyggnad, Stockholm, Sweden.

Wirén L. 2002. Dynamik i urbana nätverk- sociala och ekologiska perspektiv på förvaltningen av Nationalstadsparken i Stockholm. Degree project 2002:10, Department of Systems ecology, Stockholm University, Stockholm, Sweden.

\section{Informants}

Andersson, G., Project coordinator of the Tyreså Watershed project

Axelsson, R., Civil servant at the planning division at Stockholm County Administration

Eriksson 1, R. G., Chief gardener at Solna Municipality

Eriksson 2, R., Practical management director at Akademiska hus AB

Främborg, J., Manager at Skrubba Gård

Halling, C., Civil servant at planning division at Stockholm County Administration

Karlström, G., Head of the Fornminnesgruppen in Flaten

Lehtimaa, E., Director of the southern region cemetery management, Stockholm Cemetery

Administration

Linder, P., Managing director at planning division at Solna Municipality

Lindgren, G., Environmental advisor at Stockholm Vatten AB

Matzon, C., Managing director of the Tyresta forest

Niklasson, H., Practical management director concerning forests at Royal Djurgården Administration

Nilsson 1, H., Ecologist at the Park management Administration, Stockholm Municipality

Nilsson 2, J., Civil servant at Planning Administration, Stockholm Municipality

Nordström, L., Practical management coordinator at Stockholm Cemetery Administration in Stockholm Woodland Cemetery

Olsson 1, B., Chairman of the Southern local group of Swedish Society for Nature Conservation

Olsson 2, B., Technical director of Stockholm Cemetery Administration

Rönnbäck, H., Antiquarian at Stockholm City museum

Wallström, B., Chief of management of the Sörentorp estate owned by Vasakronan

Westerdahl, M., Consultant at SWECO 
APPENDIX 3 Brief description of each green space study area (Table 2, Borgström 2003)

\section{The National Urban Park}

The National Urban Park is a $27 \mathrm{~km}^{2}$ green area within the city of Stockholm that has been intensively managed for several hundreds years resulting in high natural and cultural values (Barthel et al. 2005). These values were publicly noticed during the end of the 2000th century when the exploitation pressure increased. This opinion finally resulted in a unique, legal protection of the area as a National Urban Park in 1995. Since then the legal protection has been tested in several juridical trials, concerning exploitation plans (Wirén 2002) and still two thirds of the land is unexploited (Länsstyrelsen i Stockholms län 1999). The diverse historical land use has created a mosaic of biotopes where the northern parts are dominated by forests and the southern by designed parks. The biological diversity is especially rich, with for example 100 breeding bird species and 800 plants (Samfundet S:t Erik Stockholm 1995). Many of the species are dependent of the old-growth nemoral forest, primarily the Oaks, Querqus robur. The watercourses in the park suffer from eutrophication and pollution, and most of them are classified as especially sensitive. Three small wetlands constitute rich bird habitats of importance regionally (Stockholm Stad 2002). From the first human settlements during the Iron Age to the era of monasteries, ending in the 1680s, the agricultural land use was intensified (Länsstyrelsen i Stockholms län 1999). In the 1600th century the Crown confiscated the land but it remained used for growing crops and grazing. In the 1680s the Crown converted a major part of the area into a hunting park and the Royal Djurgården Administration, RDA, became the primary manager. When hunting became outdated the following royalties created several palaces with surrounding parks and thereby founding many of today's cultural values. Since 1809 the Swedish State owns the area, but it is still under the disposition of the Crown (Samfundet S:t Erik Stockholm 1995) and the RDA manages almost 80 per cent (Niklasson pers.com.). The dominating landowners are the Swedish State, the RDA, two real estate companies and the Stockholm Municipality. The municipalities of Stockholm and Solna are juridical responsible for land use planning, aimed to safeguard public interests. Stockholm Vatten Inc. is responsible for managing the watercourses. Furthermore, the Stockholm County Administration is responsible for stakeholder coordination (Länsstyrelsen i Stockholms län 1996:2) and has gathered them into a co-operation forum aimed to create common principles of protection, management and development of the park. In the creation of the park the non-profit association Förbundet för Ekoparken acted as an umbrella for several NGOs and is now an active part of the co-ordination forum.

\section{The Stockholm Woodland Cemetery}

This cemetery of $1 \mathrm{~km}^{2}$ with more than 83000 graves constitutes 50 per cent of the total cemetery area in the Stockholm Municipality (Kyrkogårdsförvaltningen 2001). When the cemetery was created, in the 1920s, the land was dominated by thick pine forest, Pinus sylvestris, with some elements of spruce, Picea abies, and the field layer consisted of scrub (Westerdahl 1995). The current park can be roughly divided into pine forest mixed with spruce, deciduous forest and open land. A dominating element is the 130-180 years old pine trees. Since the creation of the cemetery the forest has been thinned due to natural death, digging damages on the roots and mowing close to the trunk, meanwhile natural regeneration has been inhibited due to the changes of ground cover into grass. Therefore, besides taking care of graves and mowing lawns, most management is about replanting pines. In 1994 UNESCO designated the area as a World Heritage and since then the main goal of management is to preserve the Stockholm Woodland Cemetery in perpetuity, as it was constructed in the 1920s, meanwhile continuing with the burial ceremonies (Olsson 2 pers.com.). The land is owned by the Stockholm Municipality and managed by the Stockholm Cemeteries Administration. The buffer zone outside the stone-wall is managed by district councils within the Stockholm Municipality (Olsson 2 pers.com.). Besides relatives and visitors seeking serenity, this is also a popular cultural or historical site for tourists. 


\section{The Flaten nature reserve}

This popular recreational area of $6 \mathrm{~km}^{2}$ situated $10 \mathrm{~km}$ south of Stockholm City became a nature reserve in 2004 aimed to protect both recreational and nature values. The central lake is surrounded by flat-rock pine forests and former fields and pastures in the valleys, now overgrown. The agricultural activity has declined since the beginning of the 2000th century (Lindholm et al. 2001:1-2) and the overgrown fields and pastures are the focus of today's management. Some of the pastures have been restored by clearing away woody growth followed by annual grazing or manual grass removal as a measure for increased plant diversity, while the forests are left for free development. Since the 1950s the former fields are used by allotment garden association for recreational cultivation. In the late 1990s the level of phosphorus in the lake raised markedly because of sudden increased internal releases from the bottom sediments. To restore the once good water quality, the water manager Stockholm Vatten AB, created a sedimentation dam and also treated the bottom chemically. Stockholm Municipality owns the area and is also responsible for land management in co-operation with Skrubba Farm keeping the cattle for grazing and a local group of the Swedish Society for Nature Conservation managing a former pasture (Olsson 1 pers. com). Besides people from the five allotment garden associations, the area is frequently visited by the general public for recreation purposes.

\section{The Tyresta Forest}

The Tyresta Forest is situated $20 \mathrm{~km}$ south-east of Stockholm and since 1993 the core area is protected as a National Park, $19.7 \mathrm{~km}^{2}$, with two surrounding Nature Reserves, $27.3 \mathrm{~km}^{2}$ (Naturvårdsverket 1993), acting as a buffer zone. The higher parts are covered with pine forests, Pinus sylvestris, and lower parts consist of mixed forests, wetlands and lakes. 70 per cent of the pine forest is older than 100 years, in some parts nearly 400 years old and these forests might harbour as many as 8000 species (Grundsten 2001). The forest dynamics is characterised by continuously disturbances like storm felling and fires. Historically this has been a sparsely populated area with some smaller farms using the forest only for household requirements and three farms remain in function today. Already in the 1930s Tyresta was a popular recreation area and in 1936 the Stockholm Municipality bought the land to restore these values. During the 1960s and 1970s there were several exploitation plans paralleled with attempts to enhance the formal protection that succeeded in the 1990s (Magnusson 1993). The land is mostly owned by the State and partly by the Stockholm Municipality. The management has been delegated to Tyresta Foundation consisting of representatives from the municipalities, the Swedish Environmental Protection Agency and the Stockholm County Administration.

\section{The Tyresån Watershed}

The Tyresån Watershed covers about $240 \mathrm{~km}^{2}$ with 38 lakes and approximately 200000 inhabitants (Länsstyrelsen i Stockholms län 1996:1). The water runoff starts in the higher forested areas in the west and then continues through the valleys eastward, towards the Baltic Sea. A large part of the surrounding land within the watershed is concrete, which increase pollution and creates fast runoff. In 1993 representatives from the six municipalities in the watershed, Stockholm County Administration and two water treatment enterprises formed a working team aimed to coordinate their managements. In 1995 a management plan was agreed upon, prioritizing eutrophication, acidification, nature preservation and recreation. The watershed co-operation group has no authority to make decisions or take measures and thereby the management plan has no legal status. It is the municipalities that are responsible for implementing the co-operation agreements into their respective land use plans, while the Stockholm County Administration proposes activities and act as a consultant to the municipalities. This watershed is popular for public recreation both informal and organized, for example local fishing associations. There are also several landowners and user groups like farmers and foresters, who use the land for economical purposes. 